\title{
Complex polarity pattern at the former Plio-Pleistocene global stratotype section at Vrica (Italy): Remagnetization by magnetic iron sulphides
}

\author{
Andrew P. Roberts ${ }^{\text {a,* }}$, Fabio Florindo ${ }^{\mathrm{a}, \mathrm{b}}$, Juan C. Larrasoaña ${ }^{\mathrm{a}, \mathrm{c}}$, Matthew A. O'Regan ${ }^{\mathrm{a}, \mathrm{d}}$, Xiang Zhao ${ }^{\mathrm{a}}$ \\ a National Oceanography Centre, University of Southampton, European Way, Southampton SO14 3ZH, UK \\ ${ }^{\mathrm{b}}$ Istituto Nazionale di Geofisica e Vulcanologia, Via di Vigna Murata 605, I-00143 Rome, Italy \\ c Area de Cambio Global, Instituto Geológico y Minero de España, Oficina de Proyectos de Zaragoza, C/ Manuel Lasala 44, 9B, Zaragoza 50006, Spain \\ ${ }^{\mathrm{d}}$ Department of Geology and Geochemistry, Stockholm University, SE-106 91 Stockholm, Sweden
}

\section{A R T I C L E I N F O}

\section{Article history:}

Received 19 October 2009

Received in revised form 8 January 2010

Accepted 18 January 2010

Available online 13 February 2010

Editor: P. DeMenocal

\section{Keywords:}

Pliocene

Pleistocene

Vrica

magnetostratigraphy

Olduvai

remagnetization

greigite

pyrrhotite

methane hydrate

\begin{abstract}
A B S T R A C T
The Vrica section in Calabria, southern Italy, was the global stratotype for the Pliocene-Pleistocene boundary until this boundary was redefined in 2009. Several paleomagnetic investigations have been carried out at Vrica to determine the age of the formerly defined Pliocene-Pleistocene boundary, which was a key calibration point for the astronomical polarity timescale (APTS). Each study has documented a complex polarity pattern at and above the top of the Olduvai subchron and in relation to the existence of the so-called Vrica subchron. When constructing the APTS, two alternative interpretations for the Vrica section were proposed, neither of which could be conclusively supported. Authigenic growth of magnetic iron sulphide minerals was proposed to explain the complex magnetic polarity record. Availability of a fresh $50-\mathrm{m}$ sediment core enabled us to test this possibility. Our magnetostratigraphic record is similar to that of previous studies, but it is also complex above the Olduvai subchron. We confirm abundant occurrences of authigenic greigite and pyrrhotite, along with detrital titanomagnetite. Authigenic monoclinic pyrrhotite indicates growth significantly later than deposition, and greigite can grow at any time during diagenesis, depending on the availability of dissolved iron and sulphide. The spatially variable magnetic polarity pattern at Vrica is therefore interpreted to have resulted from post-depositional magnetic iron sulphide formation at variable times. Tectonism along the Calabrian arc provides a plausible mechanism for forcing reducing fluids through the sediments, thereby supplying the dissolved ions needed to produce late diagenetic sulphide growth and remagnetization. The complex magnetostratigraphic record at Vrica was taken into account when the APTS was developed, and alternative interpretations result in a maximum age difference of $50 \mathrm{kyr}$ for the upper Olduvai reversal. Our results therefore do not undermine the APTS. Rather, they explain the complex magnetic polarity pattern at this globally important location and highlight the importance of remagnetization processes in such sediments.
\end{abstract}

(C) 2010 Elsevier B.V. All rights reserved.

\section{Introduction}

The Vrica section (Calabria, southern Italy; Fig. 1) was the global stratotype and point (GSSP) for the Pliocene-Pleistocene boundary (Aguire and Pasini, 1985) until this boundary was redefined in 2009 by the International Union of Geological Sciences upon the recommendation of the International Commission on Stratigraphy. The PliocenePleistocene boundary is now defined at the base of the Gelasian stage, but the GSSP for the base of the Calabrian stage remains at the Vrica section. The Vrica section comprises climatically controlled sedimentary cycles, including 21 organic-rich sapropel layers that were deposited during orbital precession minima and eccentricity maxima (Hilgen,

\footnotetext{
* Corresponding author. Present address: Research School of Earth Sciences, The Australian National University, Canberra, ACT 0200, Australia. Tel.: +61261252487. E-mail address: andrew.roberts@anu.edu.au (A.P. Roberts).
}

1991). Correlation of sedimentary cycles to astronomical target curves provides a precise means of determining the ages of geomagnetic reversals recorded within such sequences (e.g., Hilgen, 1991; Langereis and Hilgen, 1991; Berggren et al., 1995; Lourens et al., 1996a; Ogg et al., 2008). The conventional geomagnetic polarity timescale (GPTS), which is based on marine magnetic anomaly records, has adopted astronomically calibrated ages back to the early Pliocene (Cande and Kent, 1995), so that the astronomical polarity timescale (APTS) provides a basis for global high-precision dating (Lourens et al., 2004).

The Vrica section has been an important cornerstone for dating the Plio-Pleistocene boundary (until its redefinition in 2009) and the Olduvai subchron in the APTS. Despite its importance, the magnetostratigraphy of the Vrica section is not straightforward. Tauxe et al. (1983) interpreted the section to contain the Olduvai subchron. Normal polarities documented by Tauxe et al. (1983) at the top of the section (polarity zone N3 in Fig. 2) were later interpreted to be a weathering- 

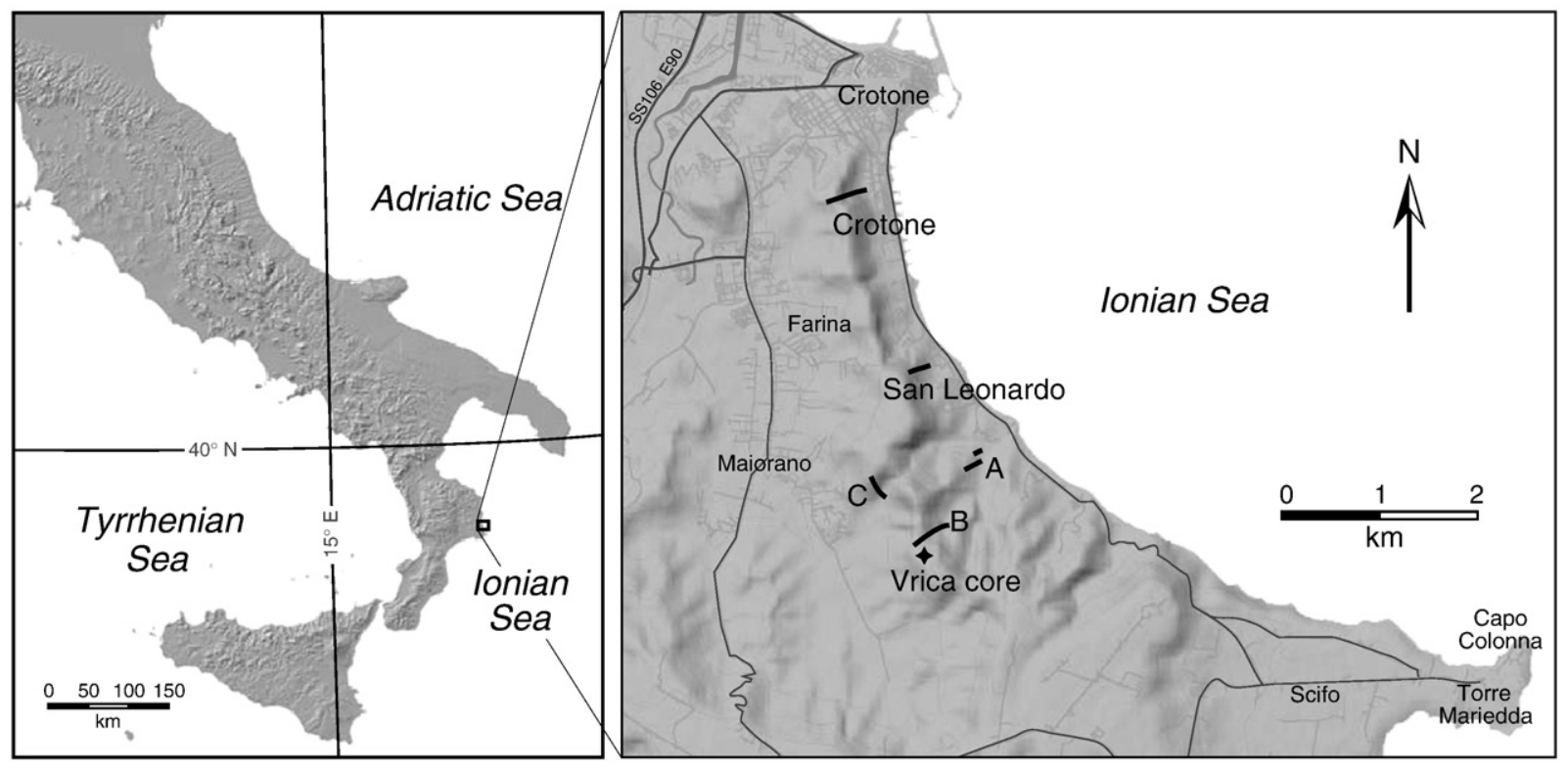

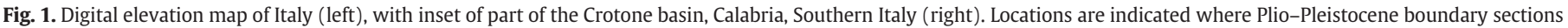
(following the pre-2009 definition) were studied by Tauxe et al. (1983) and Zijderveld et al. (1991), along with the studied Vrica core.

related secondary overprint (Zijderveld et al., 1991). The position of the upper Olduvai transition has also remained ambiguous. An interval of reversed polarity and an overlying thin normal polarity interval (Fig. 2) have been documented above the main part of the Olduvai subchron (Zijderveld et al., 1991). This resulted in two options for the upper Olduvai polarity transition (Hilgen, 1991; Zijderveld et al., 1991; Lourens et al., 1996b). In option 1, the short normal polarity interval is treated as a separate "Vrica" subchron, with the upper boundary of the main normal polarity interval interpreted as the Upper Olduvai transition. In option 2, the Upper Olduvai transition is placed at the top of the short normal polarity interval, and the interval of reversed polarity is treated as a short intra-Olduvai polarity zone. The two options represent an age difference of $50 \mathrm{kyr}$ for the Upper Olduvai transition (Hilgen, 1991). Both options are problematical because high-resolution

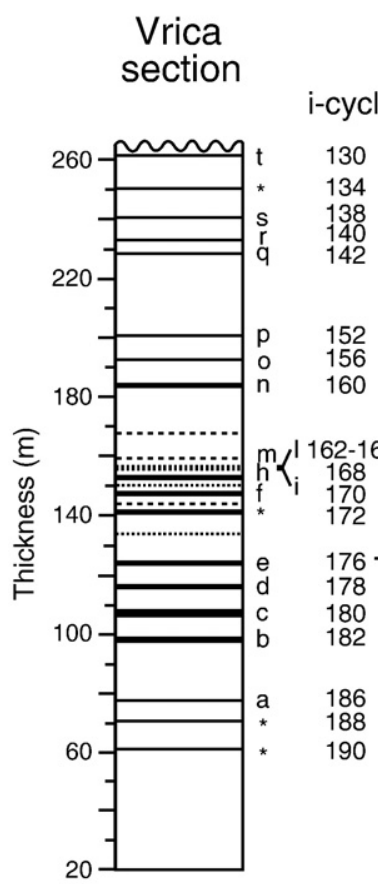

i-cycle

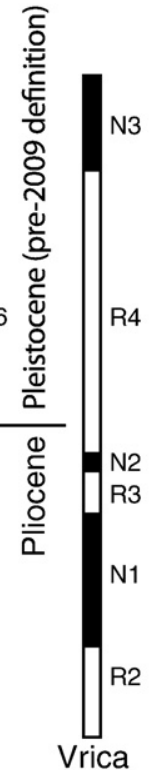

Tauxe et al. [1983]

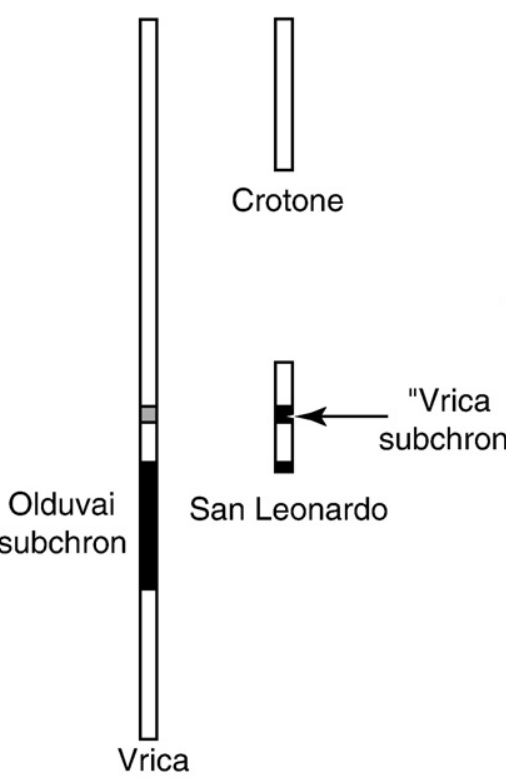

Zijderveld et al. [1991]
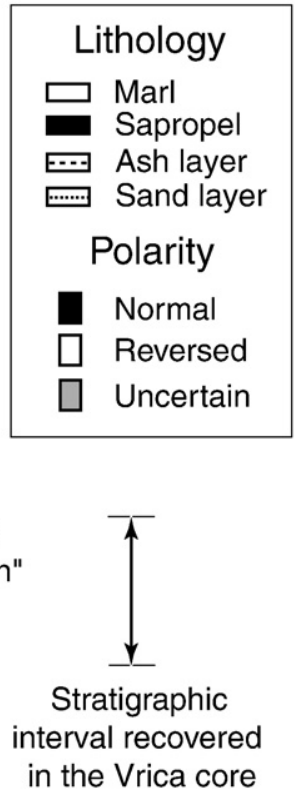

This study

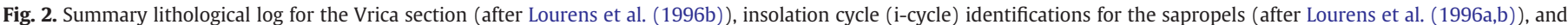

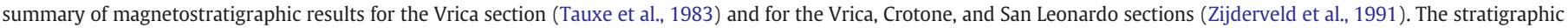

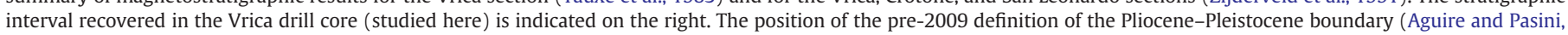
1985 ) is shown. 
analyses of rapidly deposited sediments fail to record either a short reversed polarity interval in the upper Olduvai subchron or a short normal polarity interval above the upper Olduvai transition (e.g., Guyodo et al., 2001; Channell et al., 2002).

Zijderveld et al. (1991) and Van Velzen et al. (1993) argued that magnetic iron sulphide minerals, including monoclinic pyrrhotite $\left(\mathrm{Fe}_{7} \mathrm{~S}_{8}\right)$ and greigite $\left(\mathrm{Fe}_{3} \mathrm{~S}_{4}\right)$, are potentially important carriers of the magnetic signal in the Vrica section. Lourens et al. (1996b) suggested that delayed remanence acquisition associated with iron sulphide minerals could account for the complex magnetic polarity signal in the vicinity of the Upper Olduvai transition. Greater appreciation of the complexity of magnetizations carried by magnetic iron sulphide minerals in similar sediments has been developed in recent years (e.g., Florindo and Sagnotti, 1995; Horng et al., 1998; Dinarès-Turell and Dekkers, 1999; Jiang et al., 2001; Weaver et al., 2002; Roberts and Weaver, 2005; Roberts et al., 2005; Sagnotti et al., 2005; Rowan and Roberts, 2006; Larrasoaña et al., 2007; Vasiliev et al., 2007; Rowan et al., 2009). We therefore test whether such complexities have affected the Vrica magnetostratigraphy by studying fresh, unweathered sediment from a core through this portion of the Vrica section (Negri et al., 2003).

\section{Geological setting}

The Vrica section exposes part of the Crotone basin, which is the largest Plio-Pleistocene basin in Calabria, southern Italy (Massari et al., 2002). Calabria is part of an accretionary wedge associated with subduction of oceanic crust of the Ionian Sea (e.g., Malinverno and Ryan, 1986). Syntectonic sedimentation filled the Crotone and other forearc basins in Calabria. The stratigraphic sequence of interest in this study is exposed in three partially overlapping subsections in the outskirts of the town of Crotone that are named the Vrica A, B, and C subsections (Selli et al., 1977) (Fig. 1). The composite sequence is about $240-\mathrm{m}$ thick and consists of grey-blue marly to silty marine clays. The clays commonly alternate with brownish organic-rich sapropels; sandy turbidite and volcanic ash beds are occasionally intercalated. Sedimentation occurred in a moderately deep and restricted nearshore environment with inferred paleo-water depths of between 500 and $800 \mathrm{~m}$ (Pasini and Colalongo, 1994). The sapropels and other marker beds have been informally labelled from a at the base of the sequence to $\mathrm{t}$ at the top (Selli et al., 1977), with the Plio-Pleistocene boundary being placed at the top of sapropel e (Aguire and Pasini, 1985) (Fig. 2). Lourens et al. (1996b) identified additional sapropels that are labelled with asterisks in Fig. 2. The core taken for this study was drilled in order to recover a 50-m stratigraphic interval containing the cluster of sapropels b, c, d and e that contains the Plio-Pleistocene boundary (as defined prior to 2009) and the upper Olduvai subchron (Fig. 2), as described by Zijderveld et al. (1991). We analysed a stratigraphic interval that has been the subject of much scrutiny and questioning (Hilgen, 1991; Zijderveld et al., 1991; Lourens et al., 1996b).

\section{Previous paleomagnetic studies of the Vrica section}

Paleomagnetic investigations at Vrica by Nakagawa and Niitsuma (1981) revealed a series of normal polarity zones that Tauxe et al. (1983) argued resulted from incompletely removed secondary overprints. Tauxe et al. (1983) stated that alternating field (AF) demagnetization was inadequate because it did not remove strong present-day field overprints; variable overprinting also precluded blanket demagnetization treatment. They therefore used at least 2 thermal demagnetization steps to estimate the characteristic remanent magnetization (ChRM) direction and to interpret the magnetic polarity stratigraphy (Fig. 2). Tauxe et al. (1983) reported a positive reversals test with a clockwise tectonic rotation of $15^{\circ}$. They established that the Vrica section contains the Olduvai subchron, which, combined with biostratigraphic data, provided an age estimate for the Plio-Pleistocene boundary. Much has been learned about magnetic iron sulphide minerals since the study of Tauxe et al. (1983), and many of their assumptions concerning the magnetic mineralogy at Vrica, which have important implications for the mechanism of remanence acquisition, would now be taken to suggest the presence of magnetic iron sulphides.

Zijderveld et al. (1991) sampled at considerably higher resolution than Tauxe et al. (1983) to locate and tune astronomically the ages of reversal boundaries within individual orbital precession cycles. Major differences exist in the magnetic polarity zonations from the two studies. While the magnetic polarity zonation appears to be similar around the Olduvai subchron, there is a consistent $20-25 \mathrm{~m}$ offset between the two records relative to the sapropel stratigraphy (Fig. 2). Zijderveld et al. (1991) and Lourens et al. (1996b) discuss these differences at length. Lourens et al. (1996b) discounted the possibility of sapropel misidentification because they consider the sapropel pattern to be unmistakable and because sapropels have identical labels in photographs taken from the same viewpoint by members of the two research teams. They concluded that the paleomagnetic signal is the most likely cause of the discrepancies. While this provides cause for concern in relation to a cornerstone of the APTS, it can be tested in the present study.

\section{The Vrica core}

The studied Vrica core (latitude $=39^{\circ} 03.210^{\prime} \mathrm{N}$; longitude $=17^{\circ} 08.027^{\prime}$ $\mathrm{E}$; altitude $=+75 \mathrm{~m}$ above sea level; Fig. 1) was drilled in March 1999. It was drilled to obtain unweathered sediment with better geochemical integrity and paleomagnetic potential than outcrop sediment. No sediment was recovered down to $7.8 \mathrm{~m}$ below the ground surface. Continuous core was recovered from this depth down to $50.1 \mathrm{~m}$ below the surface. The cored interval contains sapropels b, c, d and e (Selli et al., 1977), which spans insolation cycle (i-cycle) 182 (1.872 Ma) to 176 (1.808 Ma) (Lourens et al., 1996a,b). The background sediments are grey, massive (mainly bioturbated) marls. The sapropels are dark, laminated, and thick (several metres in thickness). Recovered core sections varied in length from 1.00 to $1.90 \mathrm{~m}$. After drilling, the cores were divided into subsections of variable length that were immediately wrapped in plastic film to minimize dehydration and oxidation and were stored at $4{ }^{\circ} \mathrm{C}$ at the Università degli Studi di Ancona. The lithostratigraphy of the drilled sequence was linked to the exposed sequences by visual placement of the drill rig in relation to the known outcrop stratigraphy and through detailed description of the recovered core. Absorption of water from the drilling fluid resulted in swelling of the clay component and expansion of the recovered sediments by about 20-30\%. All reported depths have therefore been corrected (by linear interpolation) using the original down-hole depth of the top and bottom of each recovered core.

\section{Methods}

The Vrica core was recovered using a CMV MK 600 rotary coring device. During drilling, the sediment rotates, twists and breaks into "biscuits" (which are also common in cores recovered by the Ocean Drilling Program using the extended core barrel (XCB) drill bit). It is impossible to recover paleomagnetic declinations from such cores because azimuthal orientation has been lost. However, reliable polarity stratigraphies can be obtained from paleomagnetic inclinations measured from samples taken from the centre of intact biscuits. In the centre of the Vrica core, intact biscuits are volumetrically dominant, which makes it possible to undertake continuous paleomagnetic measurements with uchannel samples $(2 \times 2 \mathrm{~cm}$ square cross-section). The irregular lengths of the core sections meant that individual u-channel samples sometimes constituted parts of two successive core sections. A suite of 120 discrete samples $\left(8 \mathrm{~cm}^{3}\right)$ was also collected for thermal demagnetization analysis. All paleomagnetic analyses were made in 2000 and 2001, while the samples were fresh, in the shielded laboratory at the National 
Oceanography Centre, Southampton (NOCS) using a 2-G Enterprises narrow-access pass-through cryogenic magnetometer (Roberts, 2006) with DC SQUIDs and a noise level of $1-2 \times 10^{-12} \mathrm{~A} \mathrm{~m}^{2}$. While previous studies of the Vrica sediments indicate that AF demagnetization is ineffective in removing present-day field overprints (Tauxe et al., 1983; Zijderveld et al., 1991), we used both AF and thermal demagnetization to compare their relative efficiency because the recovered sediment is fresher than outcrop sediment. The u-channel samples were demagnetized using 3 mutually orthogonal AF demagnetization coils that are arranged in-line with the NOCS cryogenic magnetometer. Successive peak AFs of $5,10,15,20,25,30,35,40,50,60,80$, and $100 \mathrm{mT}$ were applied. For thermal demagnetization, heating was successively performed at $20^{\circ}, 80^{\circ}, 120^{\circ}, 160^{\circ}, 200^{\circ}, 240^{\circ}, 280^{\circ}, 320^{\circ}, 350^{\circ}, 400^{\circ}, 450^{\circ}$, $500{ }^{\circ} \mathrm{C}$, and sometimes $550{ }^{\circ} \mathrm{C}$. The stability of the natural remanent magnetization (NRM) was assessed using vector component diagrams. ChRM directions were determined using principal component analysis (PCA) with linear best fits calculated from 4 or more demagnetization steps (Kirschvink, 1980).

AF demagnetization of u-channel samples has an additional advantage of enabling acquisition of a detailed suite of mineral magnetic measurements, including an anhysteretic remanent magnetization (ARM), an isothermal remanent magnetization (IRM) and a range of interparametric ratios. An ARM was imparted using a solenoid that is mounted in-line with the demagnetization coils on the NOCS magnetometer system (a DC bias field of $0.05 \mathrm{mT}$ was used in conjunction with a peak AF of $100 \mathrm{mT}$ ). An IRM was imparted using a stand-alone 2-G Enterprises pulse magnetizer (with a pulsed induction of $900 \mathrm{mT}$ ). Conventional hysteresis measurements (to peak fields of $\pm 1 \mathrm{~T}$ ) and first-order reversal curve (FORC) measurements (Pike et al., 1999; Roberts et al., 2000) were also made for twenty $1-\mathrm{cm}^{3}$ samples (140 FORCs were measured with an averaging time of $200 \mathrm{~ms}$ ) using a Princeton Measurements Corporation Micromag vibrating sample magnetometer. FORC diagrams were calculated with a smoothing factor (SF) (Roberts et al., 2000) of 5 using the software of Winklhofer and Zimanyi (2006).

We also examined sedimentary microtextures for 20 resin-impregnated polished sections taken from bulk sediment samples throughout the Vrica core, using a LEO 1450VP scanning electron microscope (SEM), operated at $20 \mathrm{keV}$ at NOCS. The polished sections were oriented perpendicular to the bedding plane to check whether authigenic minerals have been affected by sediment compaction. Elemental analyses were obtained using an X-ray energy-dispersive spectrometer (EDS). Spot analyses of individual mineral grains, or of clusters of grains, were carried out using a Princeton Gamma Tech (IMIX-PTS) system (2$3 \mu \mathrm{m}$ beam diameter). A pyrite standard was used to calibrate the analyses. EDS spectra have a high ratio of iron to sulphur for greigite (43\% (at.\%) Fe; $57 \%$ S) compared to pyrite (33\% Fe; 67\% S), which makes it straightforward to clearly identify the two phases. The iron to sulphur ratio for monoclinic pyrrhotite $\left(\mathrm{Fe}_{7} \mathrm{~S}_{8}\right)(47 \% \mathrm{Fe} ; 53 \% \mathrm{~S})$ is closer to that of greigite; however, these minerals can be distinguished from each other using calibrated EDS results (e.g., Weaver et al., 2002; Larrasoaña et al., 2007). Mineralogical identification is also aided by morphology (pyrrhotite is platy, while greigite occurs as octahedra). SEM observation, coupled with EDS analysis, is therefore a powerful tool for identifying sedimentary iron sulphide minerals and for establishing their relative order of authigenic growth, which can have important implications for interpreting remanent magnetizations (e.g., Jiang et al., 2001; Weaver et al., 2002; Sagnotti et al., 2005; Roberts and Weaver, 2005; Roberts et al., 2005; Larrasoaña et al., 2007).

\section{Results}

\subsection{Paleomagnetism}

U-channel data after AF demagnetization of the NRM at $30 \mathrm{mT}$ (Fig. 3, middle panel) provide an initial impression of the magnetic polarity stratigraphy for the Vrica core. The lower part of the core has normal polarity, with a transition to reversed polarity above sapropel d, as expected from Tauxe et al. (1983) and Zijderveld et al. (1991) (Fig. 2). The upper part of the core has mixed polarity (Fig. 3), and more rigorous analysis is required to assess the $30-\mathrm{mT}$ blanket demagnetization data. Much of the core is weakly magnetized but the magnetizations are well above the noise level of the magnetometer (Fig. 3, left-hand panel). The highly variable magnetic properties of the Vrica core (see below) means that it is not appropriate to carry out PCA (Kirschvink, 1980) on a predefined set of demagnetization steps. We therefore performed manual PCA analysis for measurements made at every centimetre along the core to determine the ChRM direction for each stably magnetized core position (red dots in Fig. 3, right-hand panel). Many horizons did not have a stable magnetization (Fig. $4 \mathrm{~d}, \mathrm{~h}$ ). This reduced the total number of data points from 5010 discrete positions in the u-channel measurements to 3192 data points from which a ChRM was determined (64\%). Variable demagnetization characteristics are evident. Stable ChRM directions can be determined from both AF and thermal demagnetization data (Fig. 4). Unblocking temperature spectra from thermal demagnetization results indicate the presence of (titano-)magnetite, which unblocks up to $580^{\circ} \mathrm{C}$ (Fig. $4 \mathrm{~h}$ ), a magnetic iron sulphide, which undergoes thermal decay between 270 and $350{ }^{\circ} \mathrm{C}$ (Fig. 4o), and mixtures of the two (Fig. 4e, k, n). Mineralogical variability is also reflected by coercivities from AF demagnetization data. No evidence for acquisition of a gyroremanent magnetization (GRM) was observed. A GRM has often been reported in greigite (e.g., Snowball, 1997; Sagnotti and Winkler, 1999), although Rowan and Roberts (2006) reported that GRM acquisition is not universal in greigite. In some cases, unusual demagnetization behaviour (e.g., a reversed polarity "overprint" on a normal polarity "ChRM"; Fig. 4b) suggests complex magnetizations, as discussed below.

Despite the 36\% reduction in data after ChRM analysis, the resultant polarity pattern does not change significantly (Fig. 3, right-hand panel). Abundant short-period directional fluctuations are observed, which could be artefacts associated with major NRM intensity changes in uchannel measurements, and should not be over-interpreted (Roberts, 2006). While it has been suggested that AF demagnetization does not allow adequate removal of overprints (Tauxe et al., 1983; Zijderveld et al., 1991), only 37 ChRM determinations could be made from 120 thermally demagnetized samples (red dots in Fig. 3, middle panel). These data are consistent with the overall polarity pattern. We therefore consider our ChRM results to be representative of the paleomagnetic record of the Vrica core, as summarized on the polarity log on Fig. 3.

\subsection{Rock magnetism}

The magnetic properties of the Vrica sapropels are different from those of more slowly deposited deep-sea eastern Mediterranean sapropels (e.g., Larrasoaña et al., 2003), but they are also different to those of the background Vrica sediments (Fig. 5). Low ARM values occur immediately below and above the sapropels and ARM values gradually increase above each sapropel and reach peak values $~ 1-2 \mathrm{~m}$ below the next sapropel (Fig. 5). Magnetic properties are highly variable within the sapropels, and sapropel interruptions coincide with low ARM values (e.g., sapropels $d$ and e). However, interpretation of the environmental conditions associated with these thick sapropels is not straightforward, so we avoid using the magnetic-property-based sapropel classification scheme of Larrasoaña et al. (2006). The complexly varying magnetic properties are illustrated by plotting hysteresis loops for different ARM peaks (Fig. 5). ARM peaks coincide with bulk sediment paramagnetic responses (30.33 m), pot-bellied hysteresis loops (14.42 m, $22.02 \mathrm{~m})$, or open loops with variable properties $(17.05 \mathrm{~m}, 28.86 \mathrm{~m}, 39.28 \mathrm{~m})$. Paramagnetic material cannot produce an ARM peak, so the peak at $30.33 \mathrm{~m}$ must result from localized concentrations of ferrimagnetic grains, such as iron sulphide nodules, that were not present in the measured $1-\mathrm{cm}^{3}$ sample.

FORC diagrams provide further information about the variable magnetic properties of the Vrica sediments. Strongly interacting 


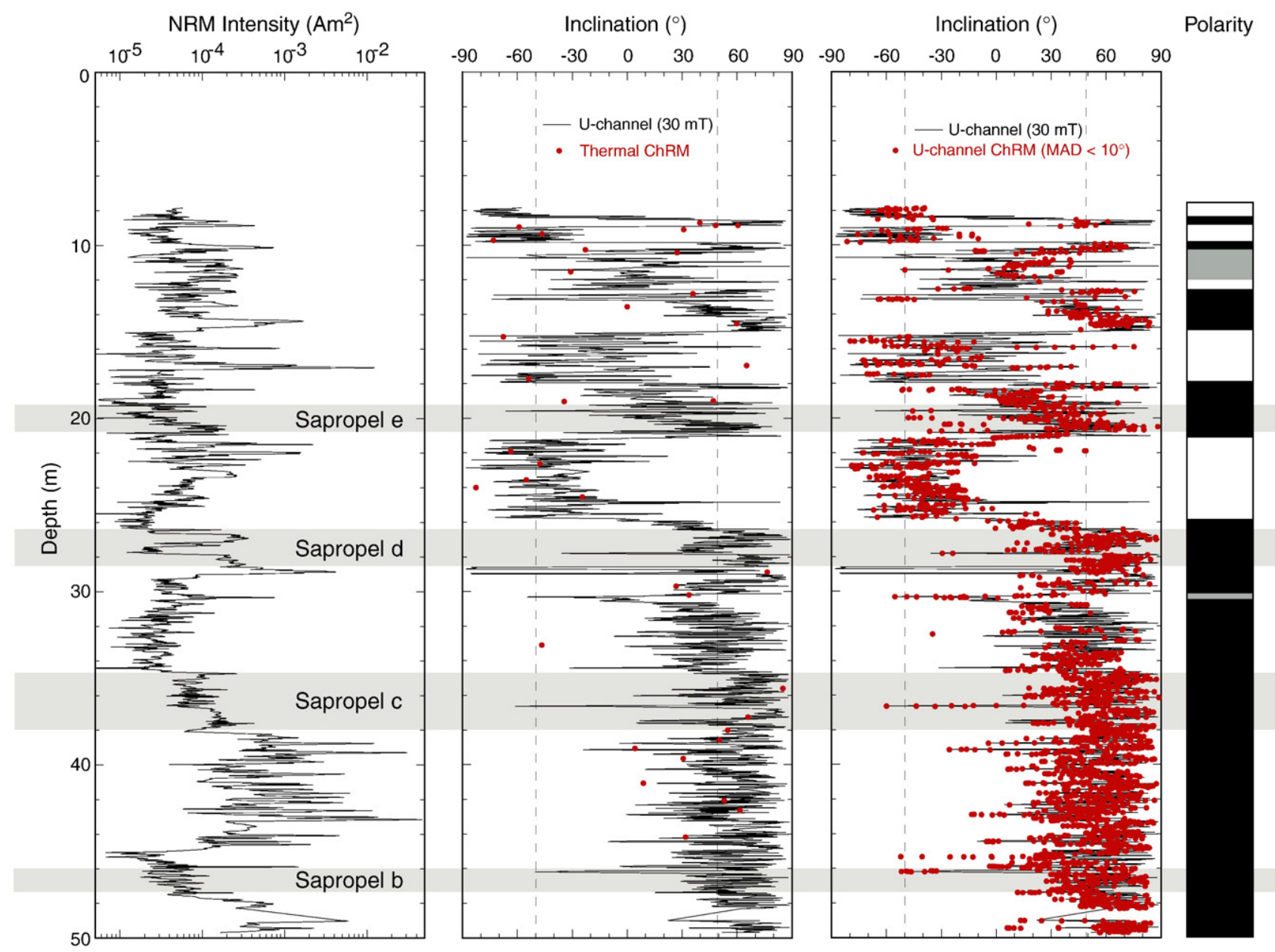

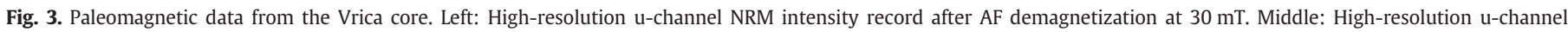

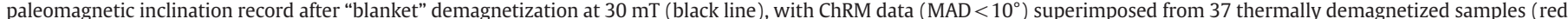

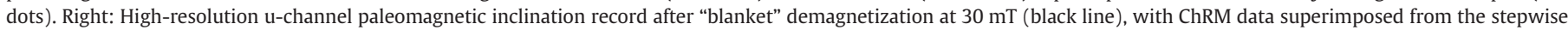

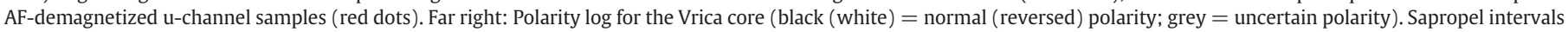
are indicated by shading. Dashed vertical lines indicate the expected inclination for a geocentric axial dipole field at the latitude of the Vrica core.

single domain (SD) magnetic particle assemblages with a coercivity peak at 50-65 mT (Fig. 6a, f) are evident for samples from $14.42 \mathrm{~m}$ and $39.28 \mathrm{~m}$, which is characteristic of greigite (Roberts et al., 2000, 2006; Rowan and Roberts, 2006; Florindo et al., 2007; Vasiliev et al., 2007). The hysteresis loop for the sample from $14.42 \mathrm{~m}$ is pot-bellied and less open than that from $39.28 \mathrm{~m}$ (Fig. 5), and more of the FORC distribution lies near the origin of the plot (Fig. 6a). This indicates a contribution from grains near the superparamagnetic (SP) threshold grain size (Pike et al., 2001), which is consistent with the pot-bellied hysteresis loop (Tauxe et al., 1996). The sample from $17.05 \mathrm{~m}$ has a peak coercivity of $\sim 12 \mathrm{mT}$ and more open outer FORC contours (Fig. 6b) that are characteristic of fine pseudosingle domain (PSD) magnetite (Roberts et al., 2000; Muxworthy and Dunlop, 2002). The FORC distribution for the sample from $22.02 \mathrm{~m}$ lies dominantly in negative Bi-space, with high peak coercivities of $55-60 \mathrm{mT}$, a negative region immediately below the main peak, and moderate magnetostatic interactions (Fig. 6c). This FORC diagram is different to those for greigite. Similar FORC distributions have been observed for samples containing diagenetic monoclinic pyrrhotite (Weaver et al., 2002; Larrasoaña et al., 2007). The kidney-shaped distribution remains unexplained, but similar distributions have been observed for hematite (Muxworthy et al., 2005), which, like pyrrhotite, has anisotropy confined to the crystallographic basal plane. The FORC distribution for the sample from $28.86 \mathrm{~m}$ (Fig. 6d) appears to be a composite between those in Fig. 6b and c, with a mixture of low-coercivity $(\sim 18 \mathrm{mT}) \mathrm{SD}$ magnetite, and the kidney-shaped pyrrhotite distribution. Stable SD magnetite is unusual in sedimentary detrital magnetite assemblages, which could indicate that the magnetite has an authigenic or biogenic origin. Passier et al. (2001) suggested that magnetite can form authigenically near sapropels in eastern Mediterranean sediments, which could explain this observation. The FORC distribution for the dominantly paramagnetic sample at $30.33 \mathrm{~m}$ (Fig. 6e) has a low

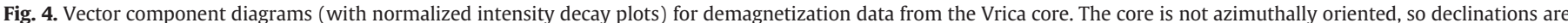

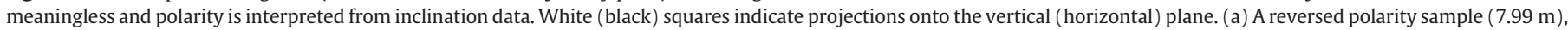

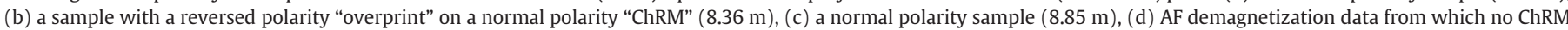

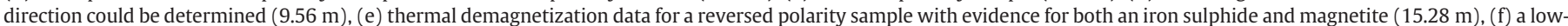

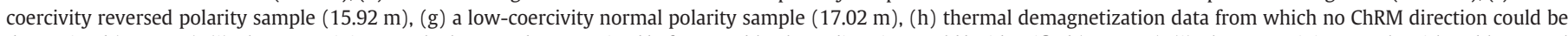

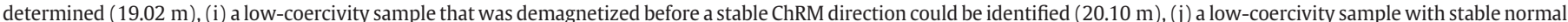

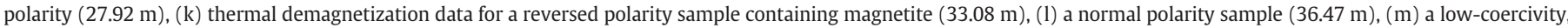

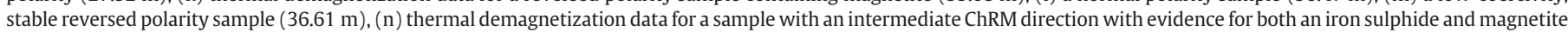
(39.05 m), and (o) thermal demagnetization data for a stable normal polarity sample with evidence for an iron sulphide (42.63 m). 
(a) $7.99 \mathrm{~m}$

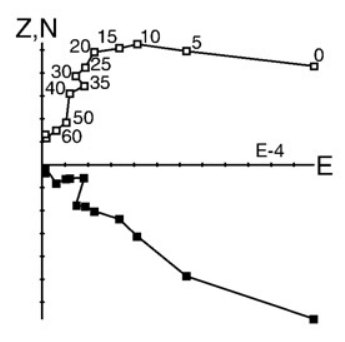

(d) $9.56 \mathrm{~m}$

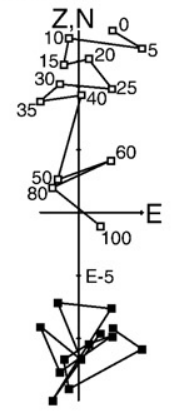

(g) $17.02 \mathrm{~m}$

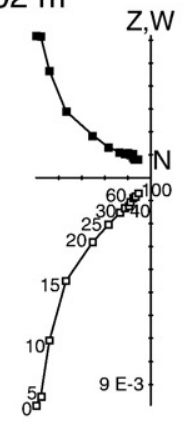

(j) $27.92 \mathrm{~m}$

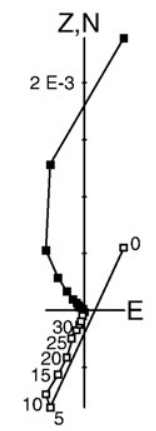

(m) $36.61 \mathrm{~m}$
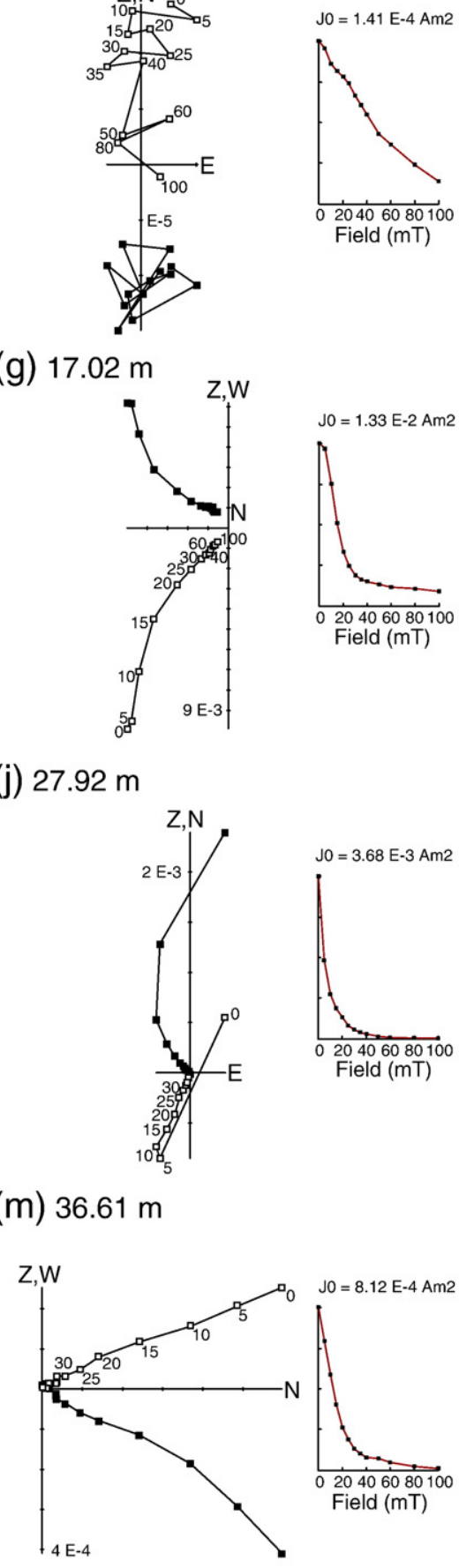

Field (mT)

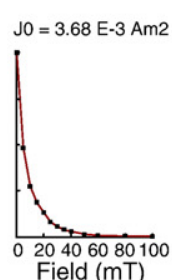

(b) $8.36 \mathrm{~m}$

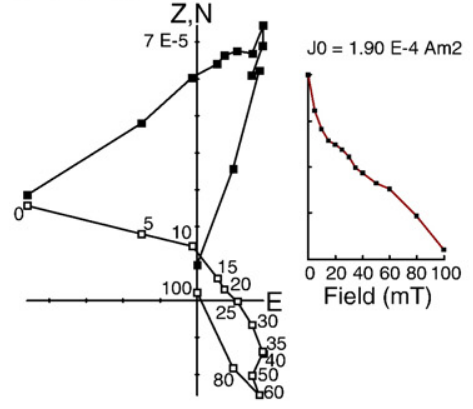

(e) $15.28 \mathrm{~m}$

(k) $33.08 \mathrm{~m}$
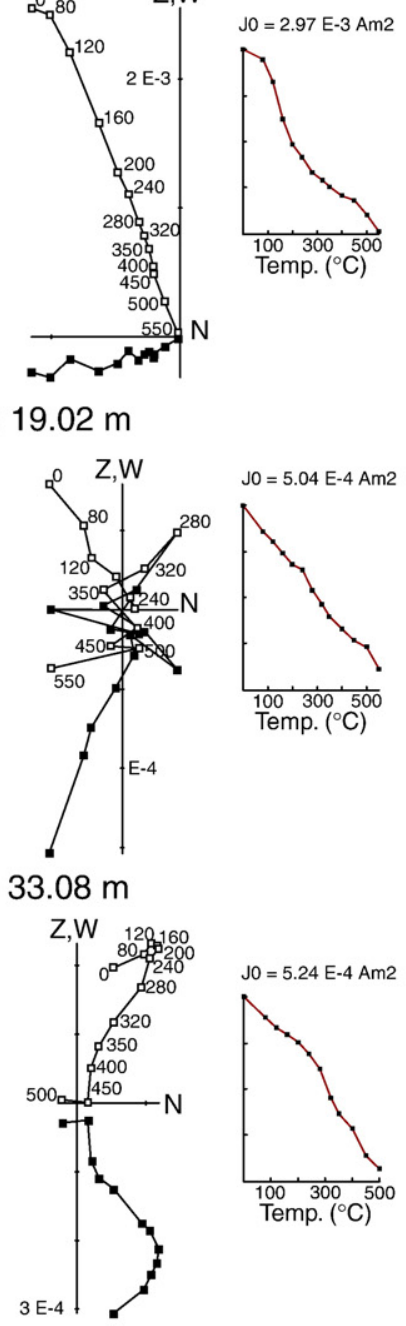

Z,W

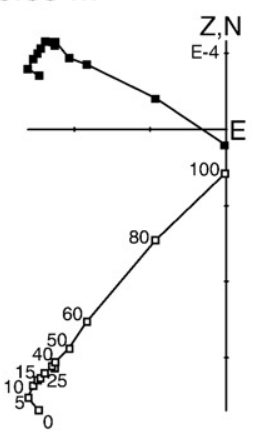

(f) $15.92 \mathrm{~m}$

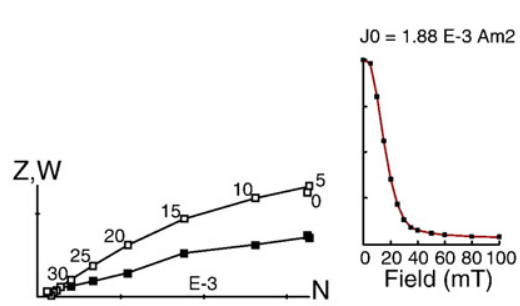

(i) $20.10 \mathrm{~m}$

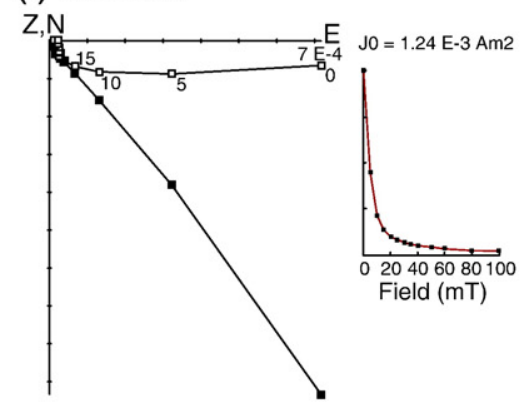

(I) $36.47 \mathrm{~m}$

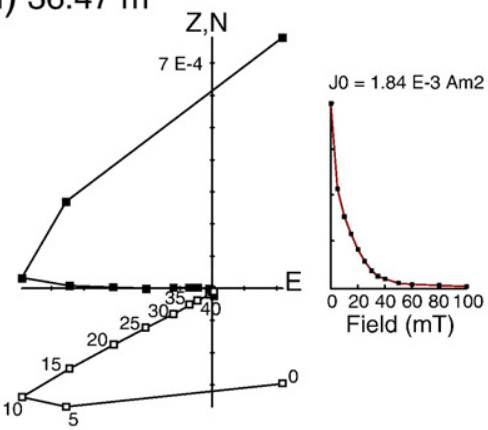

(n) $39.05 \mathrm{~m}$ Z,W

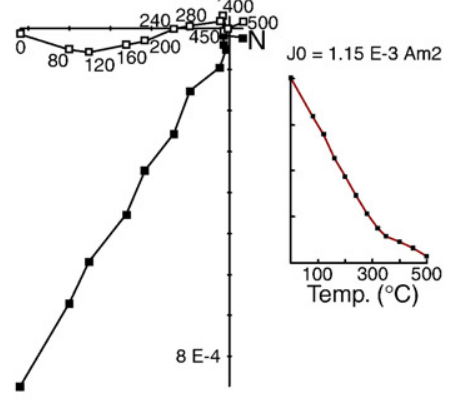

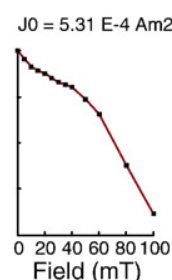

Field (mT) (o) $42.63 \mathrm{~m}$

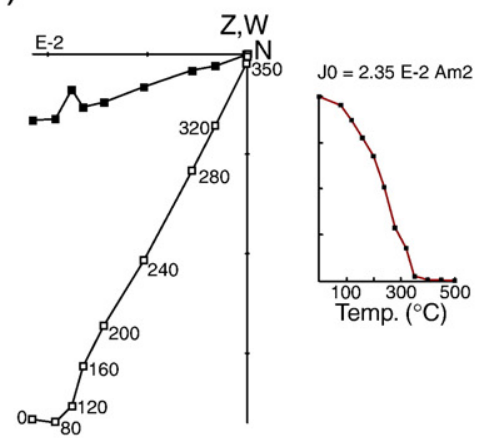


$\operatorname{ARM}(\mathrm{A} / \mathrm{m})$

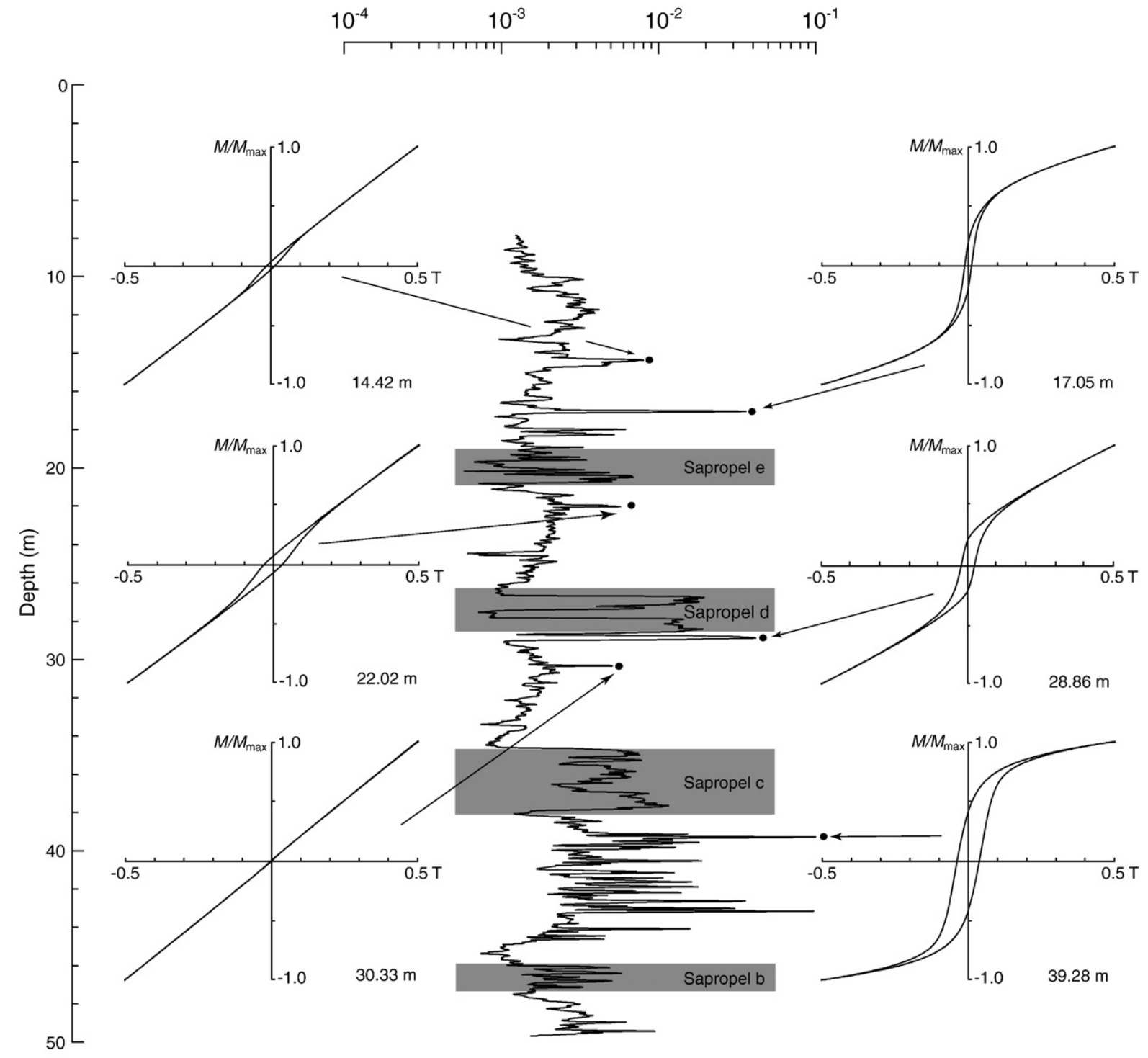

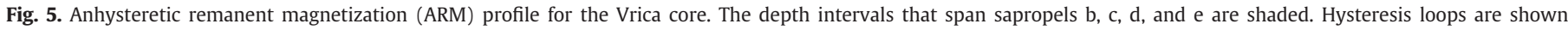
(uncorrected for paramagnetic slope) for selected ARM peaks to illustrate the wide range of magnetic properties associated with these peaks. See text for discussion.

coercivity with mainly thermally relaxed grains near the SP/SD threshold size (Pike et al., 2001). Such FORC diagrams are commonly observed for sediments where a large volume of nanoparticulate greigite has grown from solution (Rowan and Roberts, 2006; Rowan et al., 2009).

Greigite (Snowball, 1991; Roberts and Turner, 1993) and pyrrhotite (Peters and Dekkers, 2003) are both characterized by high IRM $/ \chi$ ratios. We plot $\chi$ versus IRM/ $\chi$ in Fig. 7a and IRM/ $\chi$ versus depth in Fig. 7b to test whether it is possible to identify the stratigraphic ranges of these minerals. The data distribution in Fig. 7a is nearly identical to that of complex mixtures of magnetite, greigite and pyrrhotite from Hydrate Ridge, Cascadia convergent margin (Larrasoaña et al., 2007). Samples with high $\chi$ and low IRM $/ \chi$ are interpreted to represent coarsegrained terrigenous layers, while the high IRM $/ \chi$ values represent magnetic iron sulphides. The large cluster of points with low IRM $/ \chi$ values are dominated by background paramagnetic clays. While iron sulphides have clearly given rise to a number of ARM (Fig. 5) and IRM/ $\chi$ peaks (Fig. 7b), these peaks have complex and variable magnetic mineralogy (Figs. 5-7). Also, the range of IRM/ $\chi$ values for titanomag- netite, magnetite, greigite and pyrrhotite overlap to varying extents (Peters and Dekkers, 2003). This precludes screening of the Vrica core for a "primary" detrital magnetic signature using magnetic parameters such as IRM $/ \chi$.

\subsection{Sediment microtextures from SEM observations}

Sediment microtextures provide evidence concerning diagenetic conditions and their effect on the magnetic signal. The Vrica sediments contain minerals typical of siliciclastic sediments, including quartz, feldspars, phyllosilicates, etc. Magnetic minerals with high electron backscatter are not abundant, which is consistent with the generally weak magnetizations (Fig. 3, left-hand panel). Detrital titanomagnetite grains occur in various sizes, but larger grains $(>10 \mu \mathrm{m})$ are the more obvious survivors of reductive diagenetic dissolution (Fig. 8a). Authigenic iron sulphides, including pyrite (Fig. 8a-c, f) and pyrrhotite (Fig. 8d, e, g, h), are often observed between the sheets of phyllosilicate grains. Iron sulphides are also present as nodules (Fig. 8b, c), framboids (Fig. 8f) or polyframboidal aggregates (Fig. 8i) within the sediment 
(a) $14.42 \mathrm{~m}$

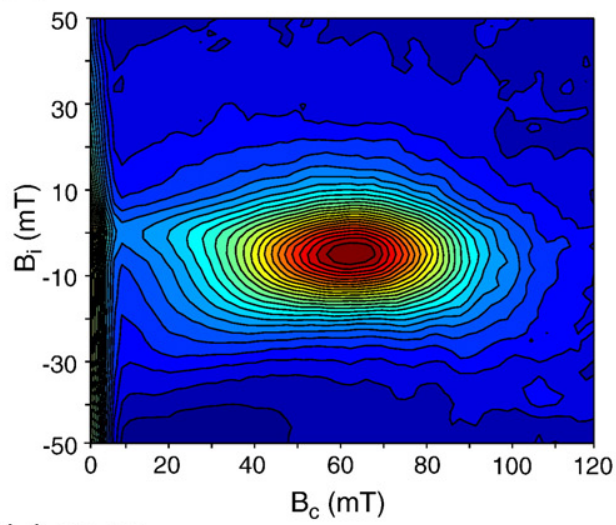

(c) $22.02 \mathrm{~m}$

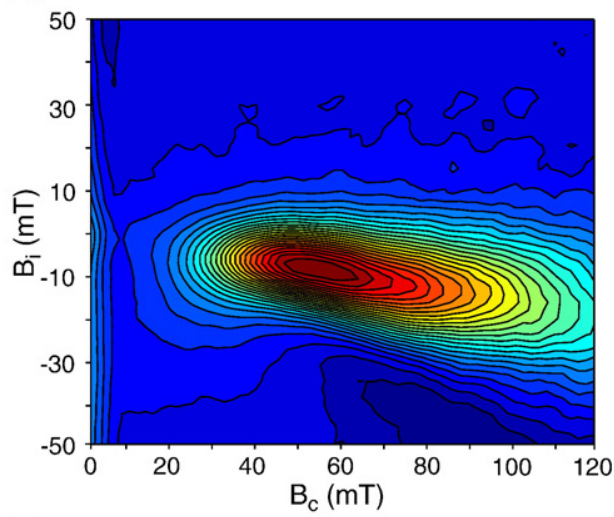

(e) $30.33 \mathrm{~m}$

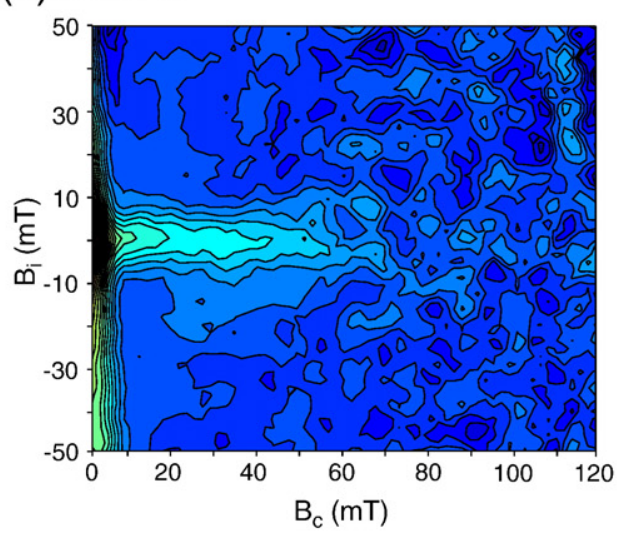

(b) $17.05 \mathrm{~m}$

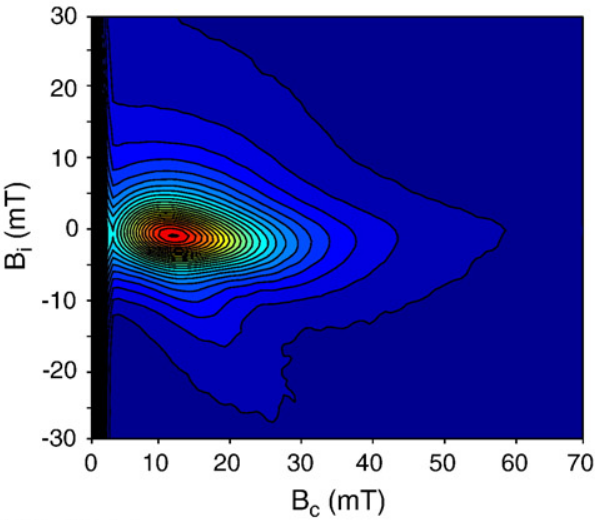

(d) $28.86 \mathrm{~m}$

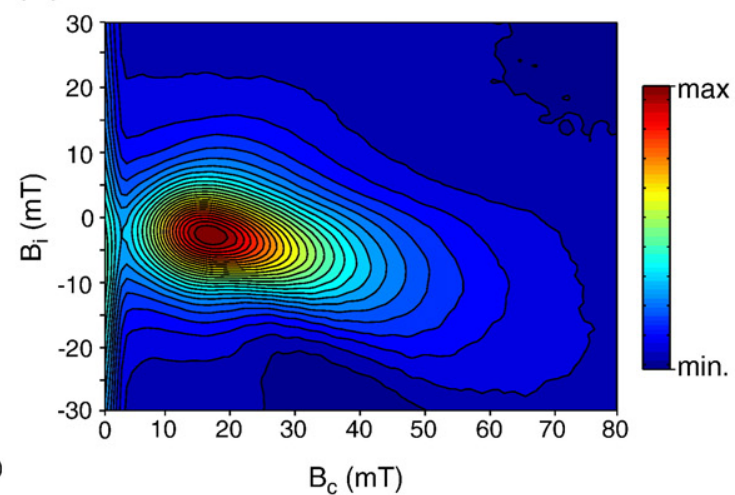

(f) $39.28 \mathrm{~m}$

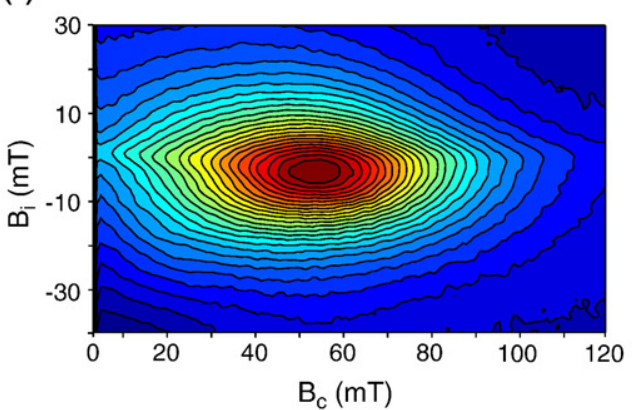

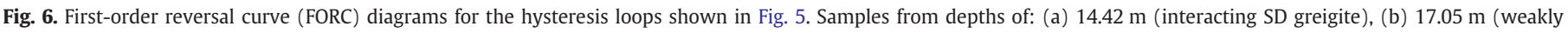

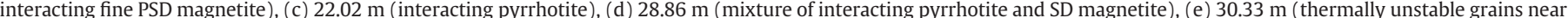

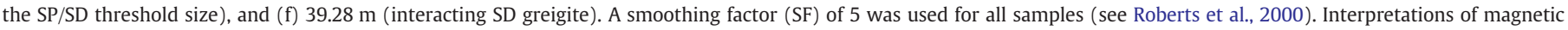
mineralogy are based on coercivities (with literature comparisons; see text for discussion) and constraints from SEM observations from the same samples (see Fig. 8).

matrix. The iron sulphides are dominated by pyrite, but framboidal greigite is also abundant (Fig. 8f, i). The abundant nodules and polyframboidal aggregates probably represent remineralized organic matter; linear bands within the nodular pyrite appear to be replacements of pre-existing plant matter (Fig. 8b, c).

Framboidal pyrite within the sediment matrix (Fig. 8f, i) often has euhedral overgrowths (higher electron backscatter with individual grains (indicated as P1) less clearly evident). Raiswell (1982) suggested that framboidal and euhedral pyrite form in a paragenetic sequence with evolving pore waters during early diagenesis. Framboidal pyrite is expected to grow early in the presence of abundant reactive iron, but as reactive iron is exhausted and sulphate reduction rates decrease, euhedral pyrite is likely to form. This suggests that the studied sediments have been subjected to prolonged early diagenetic sulphidi- zation resulting from evolving pore water compositions. The framboids with and without overgrowths represent two pyrite generations. The framboids with euhedral overgrowths are indicated in Fig. 8f as firstgeneration pyrite (P1) and those without overgrowths are indicated as second-generation pyrite (P2). Small greigite framboids (G) are present on the surfaces of both pyrite generations, which suggest that they formed at different times after both of the pyrite generations. Greigite would be expected to have a higher electron backscatter than pyrite because of its higher molecular weight. However, the observed greigite is fine-grained, therefore it has a darker contrast, probably because it has less regular surfaces that scatter electrons compared to the smoother surfaces of coarser pyrite grains.

Growth of iron sulphides on the surfaces of iron-rich sheet silicates (Fig. 8a, d, e, g, h) is common in reducing sedimentary environments 


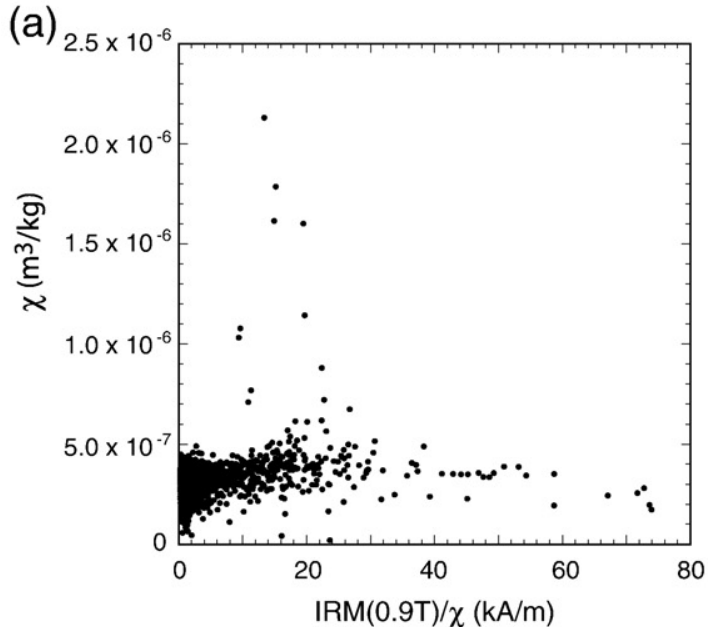

(b)
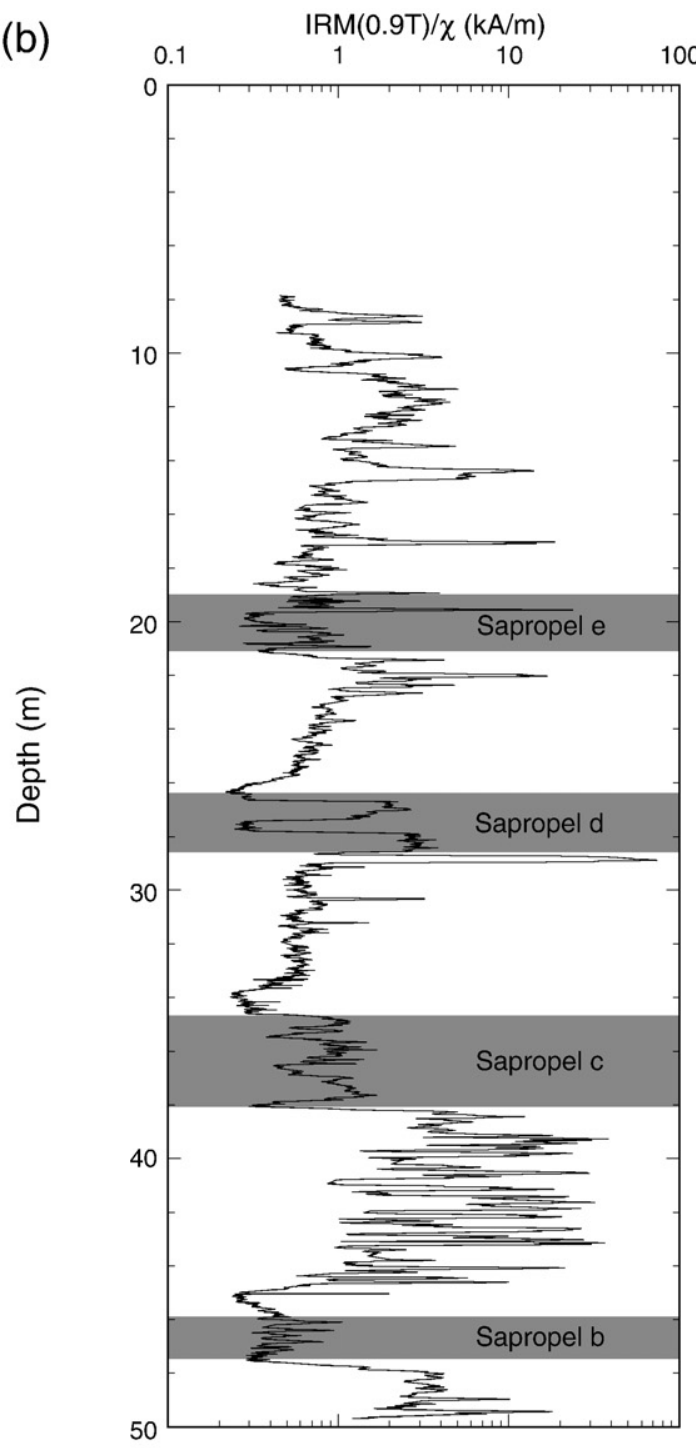

Fig. 7. (a) Plot of $\chi$ versus IRM $/ \chi$ for the Vrica core. There is a marked similarity in the data distribution between the Vrica core and sediments from Hydrate Ridge, Cascadia margin (Larrasoaña et al., 2007). (b) Down-core plot of IRM/ $\chi$ for the Vrica core. The variable magnetic properties of ARM peaks (Fig. 5) and IRM $/ \chi$ for the Vrica core preclude use of IRM/ $\chi$ for rock magnetic screening to identify a "primary" paleomagnetic signal. (e.g., Jiang et al., 2001; Roberts and Weaver, 2005), where silicates provide iron that is sulphidized to form iron sulphide. Silicates, however, do not react rapidly with dissolved sulphide (Canfield et al., 1992), so the presence of authigenic iron sulphides on the surfaces of sheet silicates is interpreted to have occurred tens of kyr after deposition (Jiang et al., 2001; Roberts and Weaver, 2005). The polished sections were taken perpendicular to bedding. There is no indication of compaction of authigenic phases, particularly for the starburst pyrrhotite textures, which indicate that the pyrrhotite has spread the silicate sheets apart during their growth (Fig. 8d, e, g, h). These textures therefore indicate that the pyrrhotite grew after sediment compaction. Individual pyrrhotite grains have long dimensions of tens of $\mu \mathrm{m}$ (Fig. 8d, $\mathrm{e}, \mathrm{g}, \mathrm{h}$ ), yet FORC diagrams for such samples indicate SD-like properties (Fig. 6c, d). This is consistent with FORC diagrams for sized pyrrhotite fractions up to $30-40 \mu \mathrm{m}$ (Wehland et al., 2005), so there is no contradiction between SEM observations and the FORC diagrams.

Nodules with mixed authigenic mineralogy (Fig. 8j-1) consist mainly of authigenic sulphides (high electron backscatter), carbonates (low backscatter), including siderite, occasional authigenic barite, and lithogenic mineral grains. Siderite forms in methanic sediments (Berner, 1981), and reacts readily with dissolved sulphide to form iron sulphide (Rickard, 1968; Furukawa and Barnes, 1996). If sulphide is re-introduced into sedimentary pore waters through disruption of the diagenetic steady state (e.g., through tectonically forced fluid migration), iron sulphides can grow on the surface of siderite (e.g., Roberts and Weaver, 2005; Sagnotti et al., 2005). Pyrrhotite plates are evident as protrusions on siderite surfaces in some nodules with mixed authigenic mineralogy (Fig. 8k). This occurrence suggests late pyrrhotite formation under methanic diagenetic conditions associated with disruption of the diagenetic steady state when dissolved sulphide was re-introduced into the sedimentary pore waters.

\section{Discussion}

\subsection{What is the real magnetic polarity pattern at Vrica?}

Three independent studies have produced 3 different magnetic polarity zonations for the Vrica section (Tauxe et al., 1983; Zijderveld et al., 1991; this study), with 15 polarity boundaries reported in different stratigraphic positions (Fig. 9a) rather than 2 (i.e., the lower and upper Olduvai transitions). Much discussion (e.g., Zijderveld et al., 1991; Lourens et al., 1996a,b) has sought to reconcile differences between the polarity zonations of Tauxe et al. (1983) and Zijderveld et al. (1991). The polarity pattern documented in both studies is similar, but is offset stratigraphically by $\sim 20-25 \mathrm{~m}$. We agree with Lourens et al. (1996b) that "the sapropel pattern is unmistakable" and that delays associated with authigenic formation of magnetic iron sulphides (Van Velzen et al., 1993) provide the most likely explanation for the documented discrepancies. We also identify a complex magnetic polarity pattern at Vrica, which contains significant variations above sapropel d. Normal polarities at the top of the record of Tauxe et al. (1983) were dismissed as weathering-induced by Zijderveld et al. (1991) who dug several metres into the outcrop to avoid weathering effects. Weathering can cause oxidation of pyrite that produces strong normal polarity overprints in such sediments (Turner, 2001; Rowan and Roberts, 2006). There is no evidence from our SEM observations that this is the cause of the variable polarity record (Fig. 9a). We sampled a fresh core to avoid surface weathering and we still obtained a highly variable paleomagnetic record. The different sampling resolution of the different studies could be partially responsible for some of the differences in the positions of polarity boundaries. The number of boundaries indicated in Fig. 9a is probably therefore not as high as the 15 indicated. Regardless, magnetic iron sulphides are abundant in the studied sediments, and some have microtextures that indicate growth after burial to the methanic diagenetic zone and after sediment compaction. The simplest explanation for the discrepancies among the different paleomagnetic studies is that the polarity patterns documented in each study represent the real 

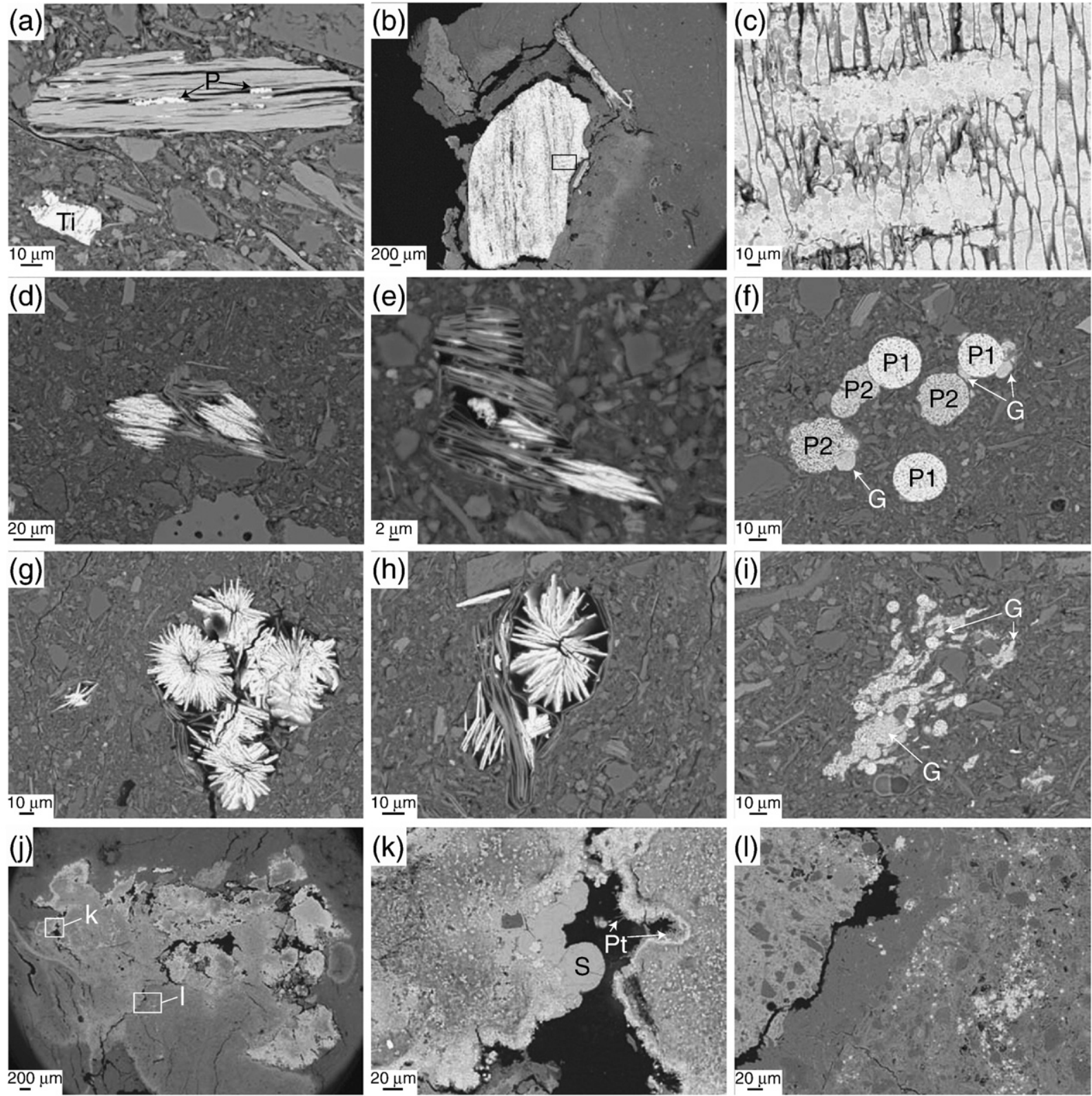

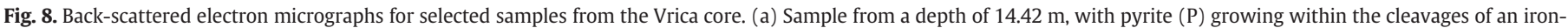

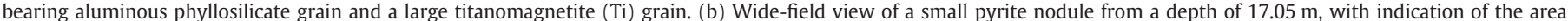

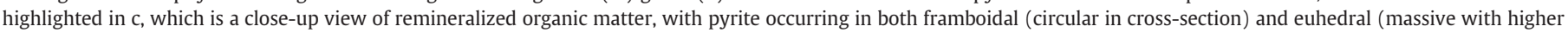

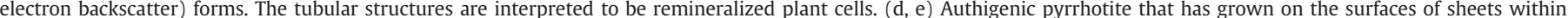

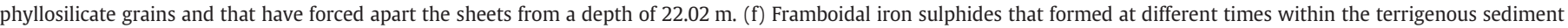

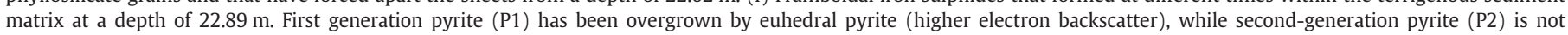

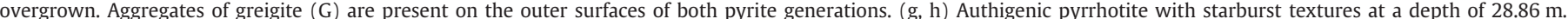

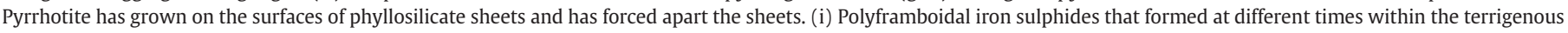

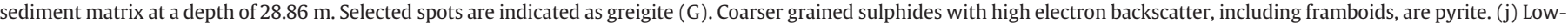

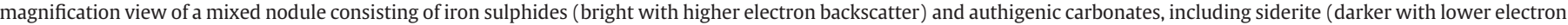

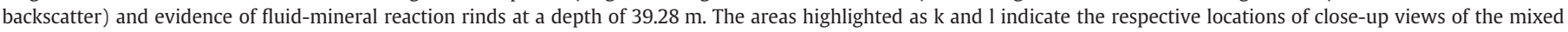
nodule. In k, siderite (S) is indicated and the needles that penetrate into the dark void in the middle of the nodule are pyrrhotite (Pt) plates.

magnetic polarity pattern at Vrica (Fig. 9a). Spatially variable remagnetizations resulting from differential iron sulphide growth at different times has been observed before (Horng et al., 1998; Rowan and Roberts, 2006), and can explain the variable polarity pattern. We therefore only agree with the first part of a concluding statement by Lourens et al. (1996b): "In conclusion, the Vrica section is not suitable for establishing a straightforward magnetostratigraphy, but this magnetostratigraphy can be unraveled once the sample resolution is sufficiently high." Our sampling resolution was effectively continuous, yet our results from fresh material remain complex. Variably timed remagnetizations linked to authigenic magnetic iron sulphide formation are more likely to be the real problem.

\subsection{Remagnetizations at Vrica}

Authigenic magnetic iron sulphide minerals are often important, if not the sole, carriers of remanent magnetizations in Italian Neogene sediments (e.g., Tric et al., 1991; Van Velzen et al., 1993; Florindo and 
(a)

$$
\begin{aligned}
& \text { Vrica } \\
& \text { section }
\end{aligned}
$$
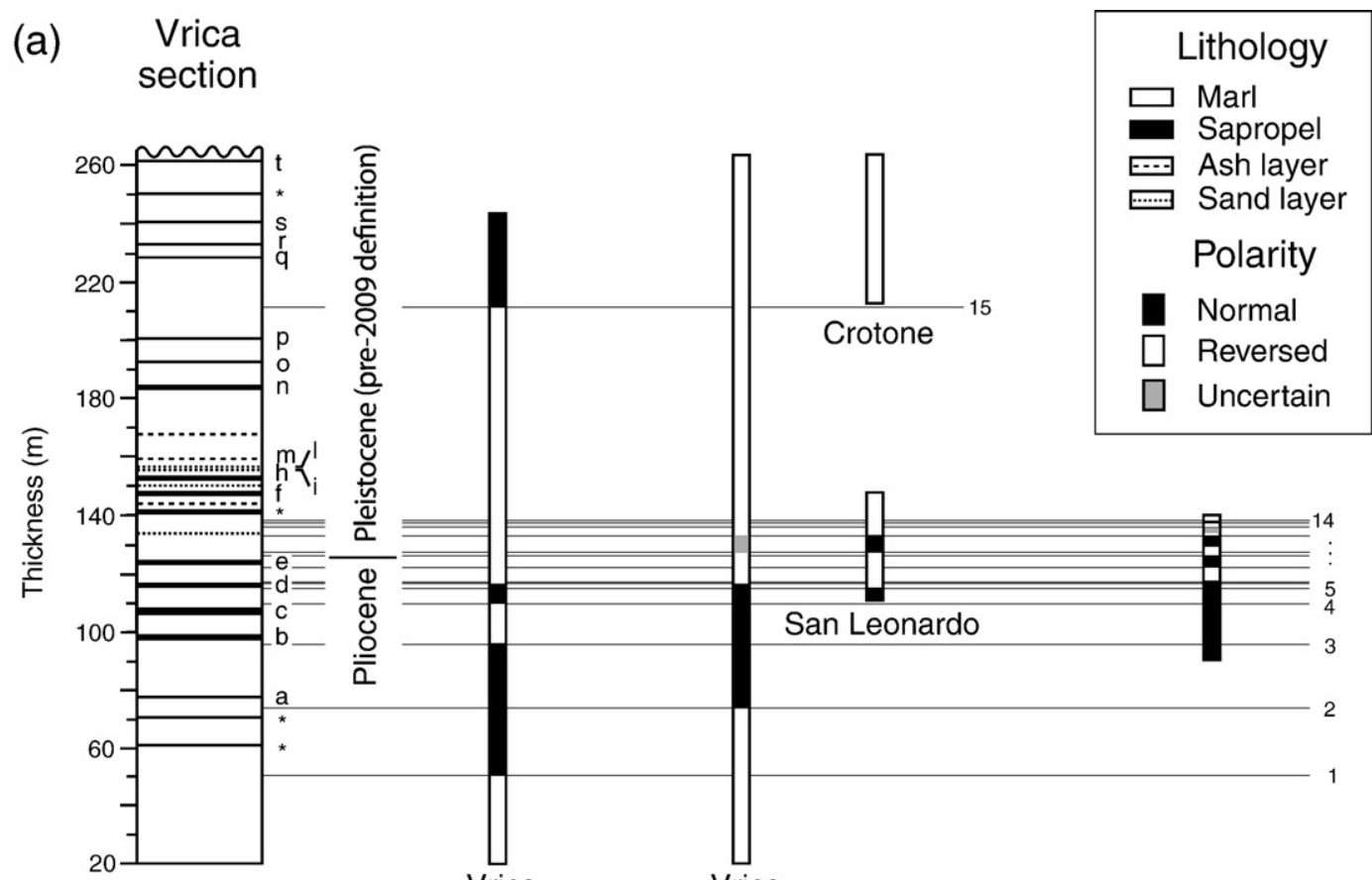

\section{(1) \\ al

$$
\begin{aligned}
& \text { Syn-depositional } \\
& \text { sulphide growth }
\end{aligned}
$$

(b)
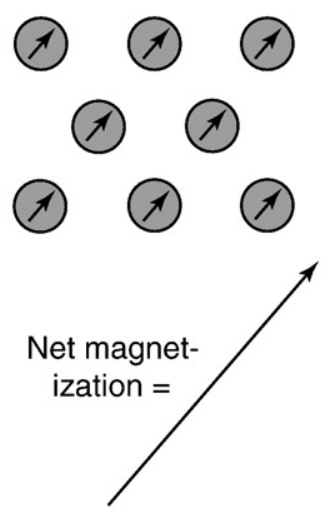

Vrica
al. [1983] $\quad$ Zijderveld et al. [1991
Dominantly syn-depositional
+ minor later sulphide growth

Vrica
al. [1983] $\quad$ Zijderveld et al. [1991
Dominantly syn-depositional
+ minor later sulphide growth

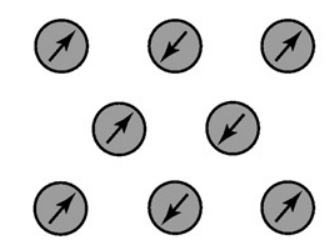

Net magnetization $=\nearrow$
Minor syn-depositional + dominantly later sulphide growth

This study

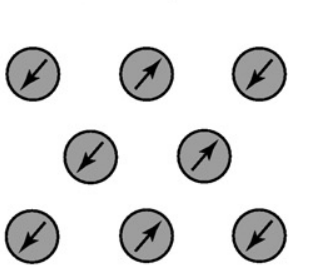

Net magnetization $=$

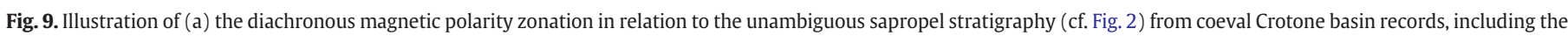

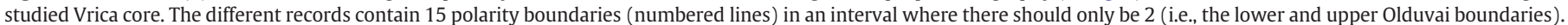

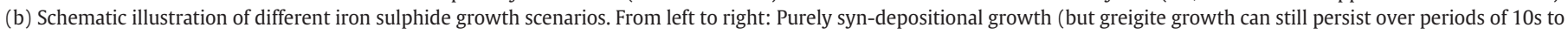

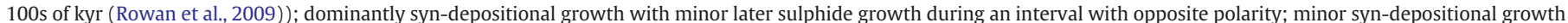

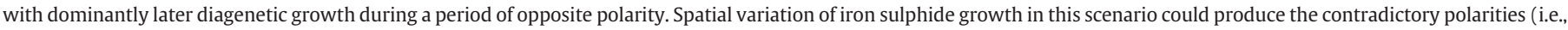

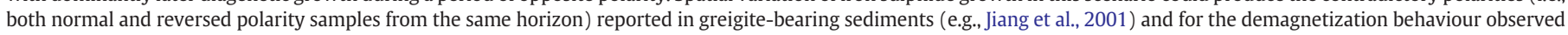
in Fig. 4b. This scenario is hypothesized to account for the diachronous polarity records from multiple studies of the Vrica section.

Sagnotti, 1995; Sagnotti and Winkler, 1999; Roberts et al., 2005; Florindo et al., 2007; Hüsing et al., 2009; Porreca et al., 2009). Italian sequences contain a range of examples where iron sulphides grew at different times during diagenesis. These range from early diagenetic syn-depositional paleomagnetic signals (Hüsing et al., 2009), to slightly delayed magnetizations (Roberts et al., 2005; Florindo et al., 2007) to late remagnetizations (Florindo and Sagnotti, 1995; Porreca et al., 2009). The likelihood that magnetic iron sulphides have complicated the paleomagnetic record at Vrica has long been recognised (Zijderveld et al., 1991; Van Velzen et al., 1993; Lourens et al., 1996b). Greigite can form at any time during diagenesis if dissolved iron and sulphide are present, which can remagnetize a sediment through a number of mechanisms (Roberts and Weaver, 2005). Paleomagnetic field tests, particularly fold tests or other convincing evidence (reversals tests can be less diagnostic), are therefore needed to confirm a syn-depositional formation of iron sulphides (Rowan and Roberts, 2006, 2008).

Magnetic iron sulphides are abundant in the Vrica sediments, as indicated by thermal demagnetization data (Fig. 4), FORC diagrams (Fig. 6) and SEM observations (Fig. 8). Sedimentary microtextures provide a range of constraints on the relative timing of iron sulphide growth. In most cases where greigite is identified, it occurs on the edges of pyrite framboids associated with two earlier generations of pyrite (Fig. 8f). This might be taken to indicate relatively late greigite formation, but similar microtextures are observed for sediments where greigite formed within tens of kyr of deposition (Roberts et al., 2005; Rowan et al., 2009), as well as for sediments with late 
remagnetizations (e.g., Roberts and Weaver, 2005; Rowan and Roberts, 2006). It is therefore difficult to definitely associate the greigite with a late remagnetization. Nevertheless, such greigite will still cause nonideal paleomagnetic recording with delayed remanence acquisition. The presence of iron sulphides within phyllosilicate sheets (Fig. 8a, d, e, g, h) indicates that the sediments have been exposed to dissolved sulphide for prolonged periods because the solubility of silicates to sulphide is low (Canfield et al., 1992). There is therefore plentiful evidence that greigite could have grown at a range of times in the Vrica sediments.

The most convincing evidence for late diagenetic iron sulphide growth is associated with pyrrhotite. Monoclinic pyrrhotite has only been reported in modern sediments as a detrital mineral because it forms too slowly to be a product of diagenetic reactions at shallow depths (Horng and Roberts, 2006). Abundant pyrrhotite in the Vrica sediments, with clear authigenic textures (Fig. 8d, e, g, h, k), even in intervals where the magnetostratigraphy of Zijderveld et al. (1991) remains unchallenged (i.e., within the Olduvai subchron), can be associated unambiguously with burial at sufficient depths that magnetization acquisition must have been delayed significantly. The starburst textures of pyrrhotite within phyllosilicate sheets (Fig. 8g, h) indicate that the pyrrhotite grew after sediment compaction. Likewise, growth of pyrrhotite on the edges of siderite nodules (Fig. 8k) indicates that it grew after the sediment had been re-exposed to pore water sulphide after burial within the methanic diagenetic zone (cf. Berner, 1981). In other settings, authigenic growth of pyrrhotite has caused NRM acquisition delays of 100s of kyr with respect to the surrounding sediment (Larrasoaña et al., 2007) and synfolding remagnetizations (Weaver et al., 2002). Disruption of steady state diagenesis can result from several mechanisms (Roberts and Weaver, 2005). Tectonism along the Calabrian arc provides the most likely cause. Major tectonic events have been recorded in the Crotone basin at $1.2 \mathrm{Ma}$ (a time of reversed polarity) and from 0.65 to $0.45 \mathrm{Ma}$ (during the Brunhes normal polarity Chron) (Massari et al., 2002). Deformation will force fluids to migrate through sediment and disrupt steady state diagenesis. Pyrrhotite and greigite with late-forming magnetizations have grown within zones of methane venting associated with gas hydrate deposits in tectonically active settings (Larrasoaña et al., 2007). The former presence of methane hydrates has also been documented in remagnetized Italian Neogene marine sediments that contain both late diagenetic greigite and hexagonal pyrrhotite (Van Dongen et al., 2007). Remagnetizations due to greigite in Taiwan (Horng et al., 1998; Jiang et al., 2001) are also likely to be associated with methane venting from hydrates. Gas hydrates have widespread distribution offshore of southwestern Taiwan and are associated with deep greigite formation (Horng and Chen, 2006). Likewise, Rowan and Roberts (2008) attributed widespread remagnetizations in New Zealand to tectonically forced fluid migrations and the former presence of gas hydrates. While direct evidence for the presence of methane hydrates is currently lacking for the Crotone basin, the magnetic properties of the Vrica sediments (Figs. 6, 7) are indistinguishable from those at Hydrate Ridge, Cascadia margin (Larrasoaña et al., 2007), and the Vrica sediments are inferred to have been deposited in a paleo-water depth range (Pasini and Colalongo, 1994) that brackets the gas hydrate stability field at Cascadia (Larrasoaña et al., 2007) and offshore Taiwan (Horng and Chen, 2006). Regardless of the possible former presence of hydrates at Vrica, evidence for late diagenetic pyrrhotite formation at Vrica is strong. Rather than assuming that most of the Vrica paleomagnetic record is reliable, we treat it as carrying at best a mixed polarity record that is at least partially remagnetized.

\subsection{What are the implications of remagnetization for the APTS?}

Paleomagnetic recording complexities in the Vrica sediments were known at the time of construction of the APTS (Hilgen, 1991; Lourens et al., 1996a,b). Neither of two options for placement of the upper Olduvai boundary at Vrica (Zijderveld et al., 1991) could be conclusively supported. Based on the reversal stratigraphy of Zijderveld et al. (1991), Hilgen (1991) reported an age of 1.790 Ma for the upper Olduvai reversal in option 2 , which he preferred, and 1.840 Ma for option 1. Complexities in the magnetic polarity pattern at Vrica were therefore known to only create a discrepancy of $50 \mathrm{kyr}$ between the two options (assuming that the rest of the polarity record is reliable). In reevaluating the Plio-Pleistocene APTS, Lourens et al. (1996a) assigned an age of $1.785 \mathrm{Ma}$ for the upper Olduvai reversal. The independent calibrations of Horng et al. (2002) and Channell et al. (2002), who both assigned an age of $1.778 \mathrm{Ma}$ for the upper Olduvai reversal, suggest that our results from the Vrica core do not have significant implications for the age of this reversal.

Alternative interpretations of the Vrica magnetostratigraphy are acceptably close to other age estimates. There are probably two reasons for this. On the one hand, it seems fortuitous that such complexly magnetized sediments have a polarity signature in a key part of the section that was probably acquired early enough to record a normal to reversed polarity transition at about the right place. Some Italian Neogene sequences have a paleomagnetic signal due to greigite that was recorded close (Hüsing et al., 2009) or reasonably close to the time of deposition (Roberts et al., 2005). In the latter case, Roberts et al. (2005) argued that the sum of the magnetizations acquired at different times determines the net magnetization direction. If the paleomagnetic signal was dominantly acquired during early burial, it will overwhelm any later diagenetic signal (Fig. 9b). This appears to be the case around the upper Olduvai reversal. Nevertheless, significantly delayed remanence acquisition is indicated by samples from depths of $22.02 \mathrm{~m}$ (Fig. 8d, e) and $28.86 \mathrm{~m}$ (Fig. 8g-i), which lie above and below sapropel $\mathrm{d}$ in the interval where a normal to reversed polarity transition is recorded. We therefore consider it to be a happy accident that the upper Olduvai reversal was identified at about the right place. On the other hand, construction of the APTS requires meticulous identification and counting of sedimentary cycles, including sapropel bundles, to correlate to astronomical target curves. The fact that a reasonable age was obtained for the upper Olduvai reversal in the APTS (Hilgen, 1991) despite complex paleomagnetic recording at the Vrica section indicates that the APTS is based upon an excellent physical stratigraphic framework. Further refinement of the age of the upper Olduvai reversal in the APTS should depend on other sections. The Vrica age determination should not be relied upon.

\section{Conclusions}

Three independent magnetostratigraphic studies of the interval containing the upper Olduvai reversal at Vrica provide contrasting results that indicate complex recording of the paleomagnetic signal in these sediments. We demonstrate that magnetic iron sulphides, which formed at variable times, are responsible for the spatially variable magnetic polarity pattern in the vicinity of the Oluvai subchron at Vrica. Tectonism along the Calabrian arc is inferred to have tectonically forced sulphidic fluids through the sediments, which produced the spatially varying remagnetizations. The complex and non-ideal nature of the magnetostratigraphic record at Vrica was known when the APTS was developed, and alternative interpretations for the upper Olduvai transition result in an age difference of only $50 \mathrm{kyr}$. Our results provide an explanation for the complex magnetic polarity pattern at this globally important location and they highlight the importance of remagnetization processes in such sediments. Nevertheless, given the complexity of the paleomagnetic record at Vrica, other records should be used to obtain refined independent astronomically calibrated estimates of the age of the upper Olduvai transition.

\section{Acknowledgements}

We thank Massimo Sarti and Michele Claps for arranging drilling of the Vrica core; Alessandra Negri and Caterina Morigi for assistance with 
sampling and for discussions; Eelco Rohling, Cor Langereis and Lisa Tauxe for discussions (although our interpretations remain our own); Kevin Padley for assistance in the NOCS paleomagnetic laboratory; and Richard Pearce for assistance with the SEM. This paper was improved as a result of constructive review comments from Cor Langereis, Mark Dekkers, Massimo Mattei and an anonymous reviewer. We also acknowledge funding from the Leverhulme Trust and European Community TMR Network contract MAG-NET (ERBFMRXCT98-0247).

\section{References}

Aguire, E., Pasini, G., 1985. The Plio-Pleistocene boundary. Episodes 8, 116-120.

Berggren, W.A., Hilgen, F.J., Langereis, C.G., Kent, D.V., Obradovich, J.D., Raffi, I., Raymo, M.E., Shackleton, N.J., 1995. Late Neogene chronology: new perspectives in highresolution stratigraphy. Geol. Soc. Am. Bull. 107, 1272-1287.

Berner, R.A., 1981. A new geochemical classification of sedimentary environments. J. Sediment. Petrol. 51, 359-365

Cande, S.C., Kent, D.V., 1995. Revised calibration of the geomagnetic polarity time scale for the Late Cretaceous and Cenozoic. J. Geophys. Res. 100, 6093-6095.

Canfield, D.E., Raiswell, R., Bottrell, S., 1992. The reactivity of sedimentary iron minerals toward sulfide. Am. J. Sci. 292, 659-683.

Channell, J.E.T., Mazaud, A., Sullivan, P., Turner, S., Raymo, M.E., 2002. Geomagnetic excursions and paleointensities in the Matuyama Chron at Ocean Drilling Program sites 983 and 984 (Iceland Basin). J. Geophys. Res. 107, B6. doi:10.1029/2001JB000491.

Dinarès-Turell, J., Dekkers, M.J., 1999. Diagenesis and remanence acquisition in the Lower Pliocene Trubi marls at Punta di Maiata (southern Sicily): palaeomagnetic and rock magnetic observations. In: Tarling, D.H., Turner, P. (Eds.), Palaeomagnetism and Diagenesis in Sediments: Geol. Soc. London Spec. Publ., vol. 151, pp. 53-69.

Florindo, F., Sagnotti, L., 1995. Palaeomagnetism and rock magnetism in the upper Pliocene Valle Ricca (Rome, Italy) section. Geophys. J. Int. 123, 340-354.

Florindo, F., Karner, D.B., Marra, F., Renne, P.R., Roberts, A.P., Weaver, R., 2007. Radioisotopic age constraints for Glacial Terminations IX and VII from aggradational sections of the Tiber River delta in Rome, Italy. Earth Planet. Sci. Lett. 256, 61-80.

Furukawa, Y., Barnes, H.L., 1996. Reactions forming smythite, $\mathrm{Fe}_{9} \mathrm{~S}_{11}$. Geochim. Cosmochim. Acta 60, 3581-3591.

Guyodo, Y., Acton, G.D., Brachfeld, S., Channell, J.E.T., 2001. A sedimentary paleomagnetic record of the Matuyama chron from the Western Antarctic margin (ODP Site 1101). Earth Planet. Sci. Lett. 191, 61-74.

Hilgen, F.J., 1991. Astronomical calibration of Gauss to Matuyama sapropels in the Mediterranean and implications for the Geomagnetic Polarity Time Scale. Earth Planet. Sci. Lett. 104, 226-244.

Horng, C.S., Chen, K.H., 2006. Complicated magnetic mineral assemblages in marine sediments offshore of southwestern Taiwan: possible influence of methane flux on the early diagenetic process. Terr. Atmos. Ocean Sci. 17, 1009-1026.

Horng, C.S., Roberts, A.P., 2006. Authigenic or detrital origin of pyrrhotite in sediments?: resolving a paleomagnetic conundrum. Earth Planet. Sci. Lett. 241, 750-762.

Horng, C.S., Torii, M., Shea, K.S., Kao, S.J., 1998. Inconsistent magnetic polarities between greigite- and pyrrhotite/magnetite-bearing marine sediments from the Tsailiao-chi section, southwestern Taiwan. Earth Planet. Sci. Lett. 164, 467-481.

Horng, C.S., Lee, M.Y., Pälike, H., Wei, K.Y., Liang, W.T., 2002. Astronomically calibrated ages for geomagnetic reversals within the Matuyama chron. Earth Planets Space 54, 679-690.

Hüsing, S.K., Dekkers, M.J., Franke, C., Krijgsman, W., 2009. The Tortonian reference section at Monte dei Corvi (Italy): evidence for early remanence acquisition in greigitebearing sediments. Geophys. J. Int. 179, 125-143.

Jiang, W.T., Horng, C.S., Roberts, A.P., Peacor, D.R., 2001. Contradictory magnetic polarities in sediments and variable timing of neoformation of authigenic greigite. Earth Planet. Sci. Lett. 193, 1-12.

Kirschvink, J.L., 1980. The least-squares line and plane and the analysis of palaeomagnetic data. Geophys. J. R. Astron. Soc. 62, 699-718.

Langereis, C.G., Hilgen, F.J., 1991. The Rosello composite - a Mediterranean and global reference section for the early to early Late Pliocene. Earth Planet. Sci. Lett. 104, 211-225.

Larrasoaña, J.C., Roberts, A.P., Stoner, J.S., Richter, C., Wehausen, R., 2003. A new proxy for bottom-water ventilation based on diagenetically controlled magnetic properties of eastern Mediterranean sapropel-bearing sediments. Palaeogeogr. Palaeoclimatol. Palaeoecol. 190, 221-242.

Larrasoaña, J.C., Roberts, A.P., Hayes, A., Wehausen, R., Rohling, E.J., 2006. Detecting missing beats in the Mediterranean climate rhythm from magnetic identification of oxidized sapropels (Ocean Drilling Program Leg 160). Phys. Earth Planet. Inter. 156, 283-293.

Larrasoaña, J.C., Roberts, A.P., Musgrave, R.J., Gràcia, E., Piñero, E., Vega, M., MartínezRuiz, F., 2007. Diagenetic formation of greigite and pyrrhotite in gas hydrate marine sedimentary systems. Earth Planet. Sci. Lett. 261, 350-366.

Lourens, L.J., Antonarakou, A., Hilgen, F.J., van Hoof, A.A.M., Vergnaud-Grazzini, C., Zachariasse, W.J., 1996a. Evaluation of the Plio-Pleistocene astronomical timescale. Paleoceanography $11,391-413$.

Lourens, L.J., Hilgen, F.J., Raffi, I., Vergnaud-Grazzini, C., 1996b. Early Pleistocene chronology of the Vrica section (Calabria, Italy). Paleoceanography 11, 797-812.

Lourens, L.J., Hilgen, F.J., Shackleton, N.J., Laskar, J., Wilson, D., 2004. The Neogene Period. In: Gradstein, F.M., Ogg, J.G., Smith, A.G. (Eds.), A Geological Time Scale 2004. Cambridge University Press, Cambridge, U.K., pp. 409-440.
Malinverno, A., Ryan, W.B.F., 1986. Extension in the Tyrrhenian Sea and shortening in the Apennines as a result of arc migration driven by sinking of the lithosphere. Tectonics 5 227-245.

Massari, F., Rio, D., Sgavetti, M., Prosser, G., D'Alessandro, A., Asioli, A., Capraro, L., Fornaciari, E., Tateo, F., 2002. Interplay between tectonics and glacio-eustasy: Pleistocene succession of the Crotone basin, Calabria (southern Italy). Geol. Soc. Am. Bull. 114, 1183-1209.

Muxworthy, A.R., Dunlop, D.J., 2002. First-order reversal curve (FORC) diagrams for pseudo-single-domain magnetites at high temperature. Earth Planet. Sci. Lett. 203 369-382.

Muxworthy, A.R., King, J.G., Heslop, D., 2005. Assessing the ability of first-order reversal curve (FORC) diagrams to unravel complex magnetic signals. J. Geophys. Res. 110, B01105. doi:10.1029/2004JB003195.

Nakagawa, H., Niitsuma, N., 1981. Magnetostratigraphy of Upper Cenozoic sections in Japan and Italy. EOS Trans. AGU 13, 517.

Negri, A., Morigi, C., Giunta, S., 2003. Are productivity and stratification important to sapropel deposition? Microfossil evidence from late Pliocene insolation cycle 180 at Vrica, Calabria. Palaeogeogr. Palaeoclimatol. Palaeoecol. 190, 243-255.

Ogg, J.G., Ogg, G., Gradstein, F.M., 2008. The Concise Geologic Time Scale. Cambridge University Press, Cambridge, U.K. 177 pp.

Pasini, G., Colalongo, M.L., 1994. Proposal for the erection of the Santernian/Emilian boundary stratotype (lower Pleistocene) and new data on the Pliocene/Pleistocene boundary stratotype. Boll. Soc. Paleont. It. 33, 101-120.

Passier, H.F., de Lange, G.J., Dekkers, M.J., 2001. Magnetic properties and geochemistry of the active oxidation front at the youngest sapropel in the eastern Mediterranean Sea. Geophys. J. Int. 145, 604-614.

Peters, C., Dekkers, M.J., 2003. Selected room temperature magnetic parameters as a function of mineralogy, concentration and grain size. Phys. Chem. Earth 28, 659-667.

Pike, C.R., Roberts, A.P., Verosub, K.L., 1999. Characterizing interactions in fine magnetic particle systems using first order reversal curves. J. Appl. Phys. 85, 6660-6667.

Pike, C.R., Roberts, A.P., Verosub, K.L., 2001. First-order reversal curve diagrams and thermal relaxation effects in magnetic particles. Geophys. J. Int. 145, 721-730.

Porreca, M., Mattei, M., Di Vincenzo, G., 2009. Post-deformational growth of late diagenetic greigite in lacustrine sediments from southern Italy. Geophys. Res. Lett. 36, L09307. doi:10.1029/2009GL037350.

Raiswell, R., 1982. Pyrite texture, isotopic composition and the availability of iron. Am. J. Sci. 282, 1244-1263.

Rickard, D.T., 1968. Synthesis of smythite-rhombohedral $\mathrm{Fe}_{3} \mathrm{~S}_{4}$. Nature 218, 356-357.

Roberts, A.P., 2006. High-resolution magnetic analysis of sediment cores: strengths, limitations and strategies for maximizing the value of long-core magnetic data. Phys. Earth Planet. Inter. 156, 162-178.

Roberts, A.P., Turner, G.M., 1993. Diagenetic formation of ferrimagnetic iron sulphide minerals in rapidly deposited marine sediments, New Zealand. Earth Planet. Sci. Lett. 115, 257-273.

Roberts, A.P., Weaver, R., 2005. Multiple mechanisms of remagnetization involving sedimentary greigite $\left(\mathrm{Fe}_{3} \mathrm{~S}_{4}\right)$. Earth Planet. Sci. Lett. 231, 263-277.

Roberts, A.P., Pike, C.R., Verosub, K.L., 2000. FORC diagrams: a new tool for characterizing the magnetic properties of natural samples. J. Geophys. Res. 105, 28,461-28,475.

Roberts, A.P., Jiang, W.T., Florindo, F., Horng, C.S., Laj, C., 2005. Assessing the timing of greigite formation and the reliability of the Upper Olduvai polarity transition record from the Crostolo River, Italy. Geophys. Res. Lett. 32, L05307. doi:10.1029/ 2004 GL022137.

Roberts, A.P., Liu, Q. Rowan, C.J., Carvallo, C., Chang, L., Torrent, J., Horng, C.S., 2006 Characterization of hematite $\left(\alpha-\mathrm{Fe}_{2} \mathrm{O}_{3}\right)$, goethite $(\mathrm{FeOOH})$, greigite $\left(\mathrm{Fe}_{3} \mathrm{~S}_{4}\right)$ and pyrrhotite $\left(\mathrm{Fe}_{7} \mathrm{~S}_{8}\right)$ using first-order reversal curve (FORC) diagrams. J. Geophys. Res. 111, B12S35. doi:10.1029/2006JB004560.

Rowan, C.J., Roberts, A.P., 2006. Magnetite dissolution, diachronous greigite formation, and magnetizations arising from pyrite oxidation: unravelling complex magnetizations in Neogene marine sediments from New Zealand. Earth Planet. Sci. Lett. 241, 119-137.

Rowan, C.J., Roberts, A.P., 2008. Widespread remagnetizations and a new view of Neogene tectonic rotations within the Australia-Pacific plate boundary zone, New Zealand. J. Geophys. Res. 113, B03103. doi:10.1029/2006JB004594.

Rowan, C.J., Roberts, A.P., Broadbent, T., 2009. Paleomagnetic smoothing and magnetic enhancement in marine sediments due to prolonged early diagenetic growth of greigite. Earth Planet. Sci. Lett. 277, 223-235.

Sagnotti, L., Winkler, A., 1999. Rock magnetism and palaeomagnetism of greigite-bearing mudstones in the Italian peninsula. Earth Planet. Sci. Lett. 165, 67-80.

Sagnotti, L., Roberts, A.P., Weaver, R., Verosub, K.L., Florindo, F., Pike, C.R., Clayton, T. Wilson, G.S., 2005. Apparent magnetic polarity reversals due to remagnetization resulting from late diagenetic growth of greigite from siderite. Geophys. J. Int. 160, 89-100.

Selli, R, Accorsi, CA Bandini Mazzanti, M., Bertolani Marchetti, D. Bigazzi, G, Bonadonna, F.P., Borsetti, A.M., Cati, F., Colalongo, M.L., D'Onofrio, S., Landini, W., Menesini, E., Mezzeti, R., Pasini, G., Savelli, G., Tampieri, R., 1977. The Vrica section (Calabria). A potential Neogene-Quaternary boundary stratotype. G. Geol. 41, 181-204.

Snowball, I.F., 1991. Magnetic hysteresis properties of greigite $\left(\mathrm{Fe}_{3} \mathrm{~S}_{4}\right)$ and a new occurrence in Holocene sediments from Swedish Lappland. Phys. Earth Planet. Inter. $68,32-40$.

Snowball, I.F., 1997. The detection of single-domain greigite $\left(\mathrm{Fe}_{3} \mathrm{~S}_{4}\right)$ using rotational remanent magnetization (RRM) and the effective gyro field $\left(\mathrm{B}_{\mathrm{g}}\right)$ : mineral magnetic and palaeomagnetic applications. Geophys. J. Int. 130, 704-716.

Tauxe, L., Opdyke, N.D., Pasini, G., Elmi, C., 1983. Age of the Plio-Pleistocene boundary in the Vrica section, southern Italy. Nature 304, 125-129.

Tauxe, L., Mullender, T.A.T., Pick, T., 1996. Potbellies, wasp-waists, and superparamagnetism in magnetic hysteresis. J. Geophys. Res. 101, 571-583. 
Tric, E., Laj, C., Jehanno, C., Valet, J.-P., Kissel, C., Mazaud, A., Iaccarino, S., 1991. Highresolution record of the upper Olduvai transition from Po Valley (Italy) sediments: support for dipolar transition geometry? Phys. Earth Planet. Inter. 65, 319-336.

Turner, G.M., 2001. Toward an understanding of the multicomponent magnetization of uplifted marine sediments in New Zealand. J. Geophys. Res. 106, 6385-6397.

Van Dongen, B.E., Roberts, A.P., Schouten, S., Jiang, W.T., Florindo, F., Pancost, R.D., 2007. Formation of iron sulfide nodules during anaerobic oxidation of methane. Geochim. Cosmochim. Acta 71, 5155-5167.

Van Velzen, A.J., Dekkers, M.J., Zijderveld, J.D.A., 1993. Magnetic iron-nickel sulphides in the Pliocene and Pleistocene marine marls from the Vrica section (Calabria, Italy) Earth Planet. Sci. Lett. 115, 43-55.

Vasiliev, I., Dekkers, M.J., Krijgsman, W., Franke, C., Langereis, C.G., Mullender, T.A.T., 2007. Early diagenetic greigite as a recorder of the palaeomagnetic signal in MiocenePliocene sedimentary rocks of the Carpathian foredeep (Romania). Geophys. J. Int. $171,613-629$.
Weaver, R., Roberts, A.P., Barker, A.J., 2002. A late diagenetic (synfolding) magnetization carried by pyrrhotite: implications for paleomagnetic studies from magnetic iron sulphide-bearing sediments. Earth Planet. Sci. Lett. 200, 371-386.

Wehland, F., Stancu, A., Rochette, P., Dekkers, M.J., Appel, E., 2005. Experimental evaluation of magnetic interaction in pyrrhotite-bearing samples. Phys. Earth Planet. Inter. 153, 181-190.

Winklhofer, M., Zimanyi, G.T., 2006. Extracting the intrinsic switching field distribution in perpendicular media: a comparative analysis. J. Appl. Phys. 99, 08E710.

Zijderveld, J.D.A., Hilgen, F.J., Langereis, C.G., Verhallen, P.J.J.M., Zachariasse, W.J., 1991. Integrated magnetostratigraphy and biostratigraphy of the upper Pliocene-lower Pleistocene from the Monte Singa and Crotone areas in Calabria, Italy. Earth Planet. Sci. Lett. 107, 697-714. 